\title{
Identifying Self-Determined Learning Practices Within Social Media for Teacher Professional Development
}

\author{
Leah Mcjilton \\ West Virginia University, Leah.mcjilton@gmail.com
}

Follow this and additional works at: https://researchrepository.wvu.edu/etd

Part of the Adult and Continuing Education and Teaching Commons, and the Educational Technology Commons

\section{Recommended Citation}

Mcjilton, Leah, "Identifying Self-Determined Learning Practices Within Social Media for Teacher Professional Development" (2021). Graduate Theses, Dissertations, and Problem Reports. 8338. https://researchrepository.wvu.edu/etd/8338

This Dissertation is protected by copyright and/or related rights. It has been brought to you by the The Research Repository @ WVU with permission from the rights-holder(s). You are free to use this Dissertation in any way that is permitted by the copyright and related rights legislation that applies to your use. For other uses you must obtain permission from the rights-holder(s) directly, unless additional rights are indicated by a Creative Commons license in the record and/ or on the work itself. This Dissertation has been accepted for inclusion in WVU Graduate Theses, Dissertations, and Problem Reports collection by an authorized administrator of The Research Repository @ WVU. For more information, please contact researchrepository@mail.wvu.edu. 
Identifying Self-Determined Learning Practices

Within Social Media for Teacher Professional Development

Leah McJilton

Dissertation submitted

to the College of Education and Human Services

at West Virginia University

in partial fulfillment of the requirements for the degree of

Doctor of Education (Ed.D.) in

Instructional Design and Technology

Ugur Kale, Ph.D., Chair

Denise Lindstrom, Ph.D.

Marjorie Darrah, Ph.D.

John Oughton, Member, Ph.D

Department of Counseling and Learning Sciences

\section{Morgantown, WV}

2021

Keywords: Teacher professional development, heutagogy, self-determined learning, social media, personal learning network (PLN)

Copyright 2021 Leah McJilton 


\author{
Abstract \\ Identifying Self-Determined Learning Practices \\ Within Social Media for Teacher Professional Development
}

\title{
Leah McJilton
}

The collective increase of learner-centered teaching and substantial technology use in the classroom has given instructors potential opportunities to support students in developing lifelong learning skills. The ability to manage one's own learning is an essential skill for lifelong learners in today's workforce. Heutagogy, or self-determined learning, suggests that individuals have agency with respect to how, what, and when they learn. Heutagogy provides a framework for making the most of these developments, drawing on established learner-centered education theories. The key principles of heutagogy provide a foundation for designing and developing learning environments using social media. In order for teachers to create learning environment that have opportunities for heutagogical learning, it is imperative that teachers successfully practice these methods themselves.

It is generally assumed that effective teacher professional development is critical to effective educational improvements and reforms of educational institutions. However, traditional teacher professional development is constrained by time and space. An alternative form of teacher professional development is needed for continual growth and development. Through the theory of heutagogy and the learner-centered pedagogies on which the theory is founded, this research project seeks to contribute to the understanding of the role of social media in supporting the development of teachers' self-determined learning practices. In particular, this study aims to examine teachers' perceptions of using social media for professional development, and show how teachers apply self-determined learning for professional development within these social media environments. 


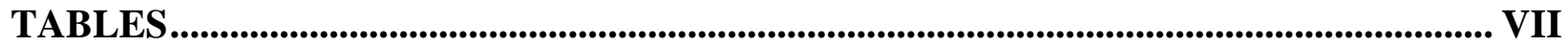

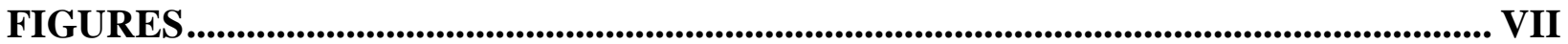

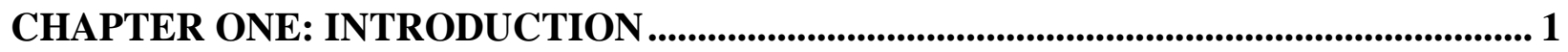

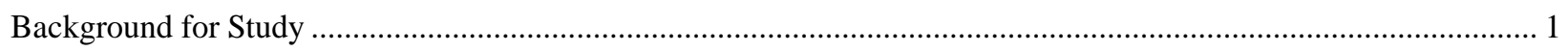

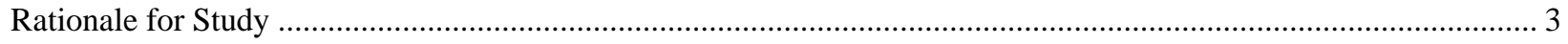

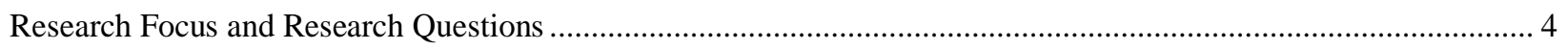

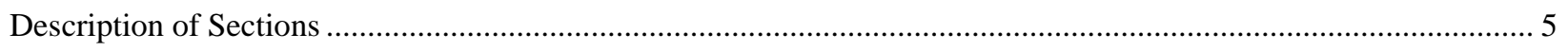

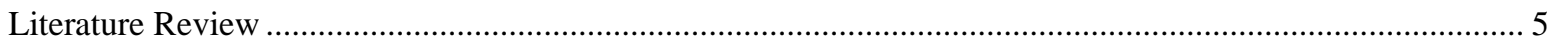

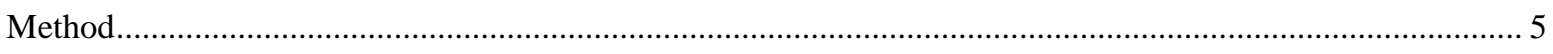

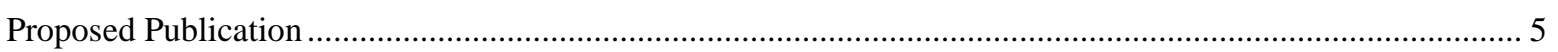

CHAPTER TWO: LITERATURE REVIEW .................................................................... 7

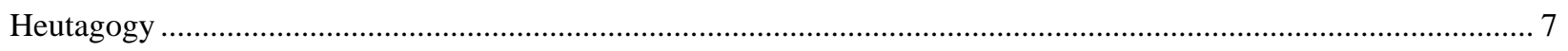

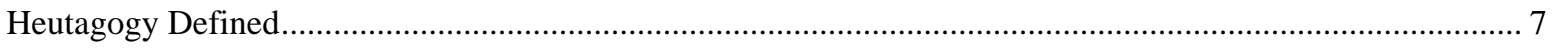

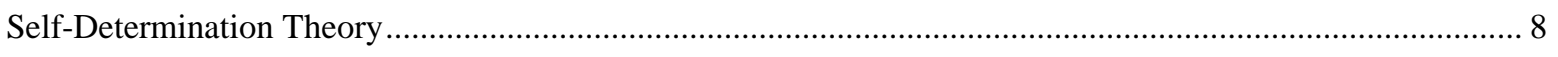

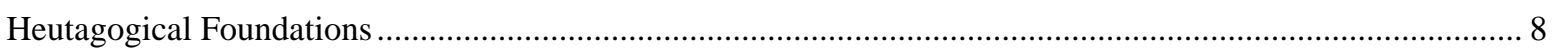

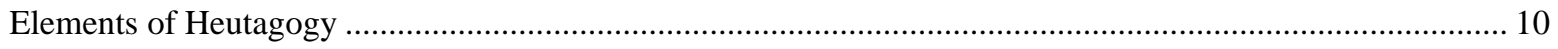

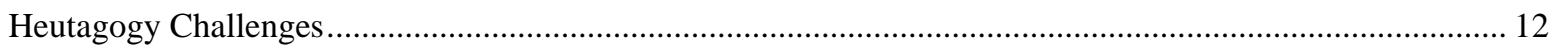

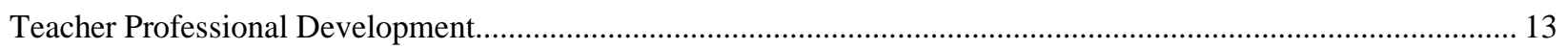

Professional Development Defined ................................................................................................ 13

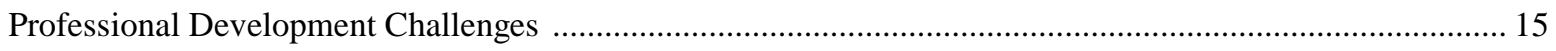

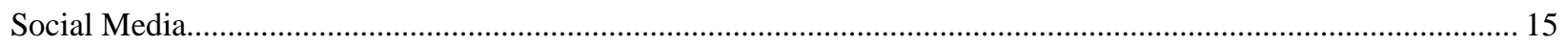




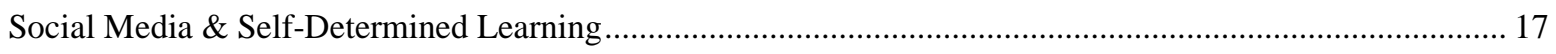

Content/Information Sharing Communities ........................................................................................... 17

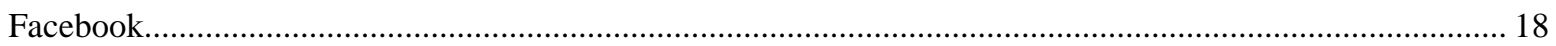

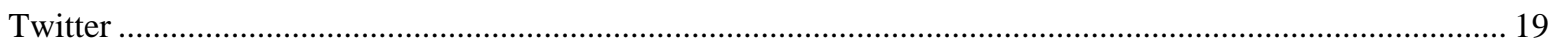

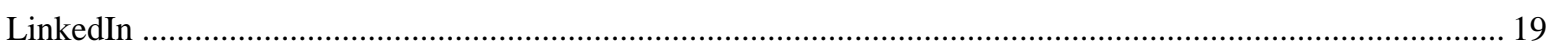

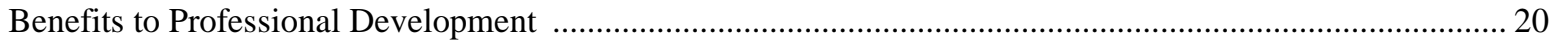

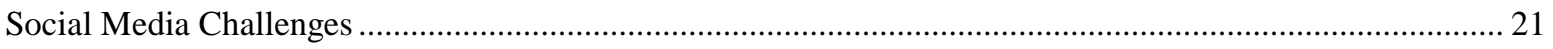

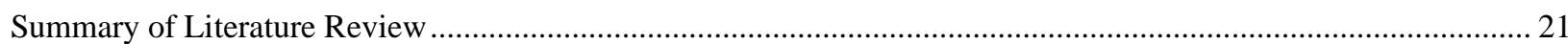

RESEARCH FOCUS AND RESEARCH QUESTIONS.......................................................... 22

CHAPTER THREE: METHODOLOGY ........................................................................ 24

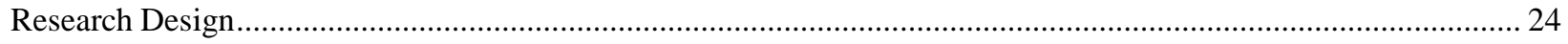

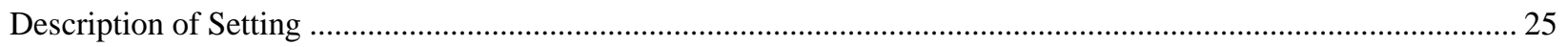

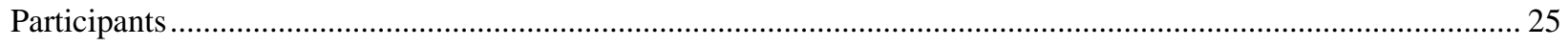

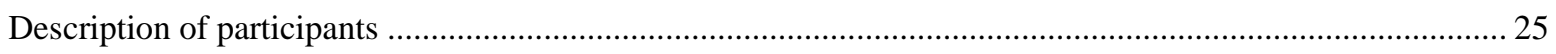

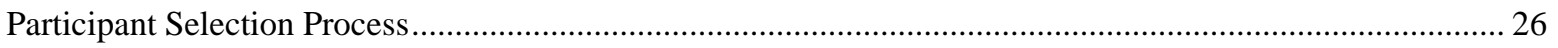

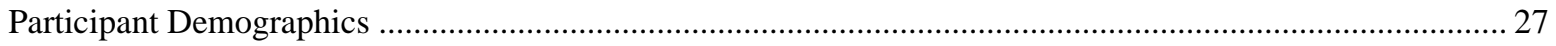

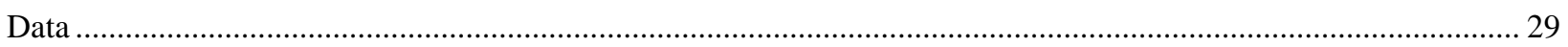

Survey

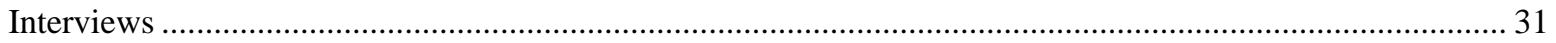

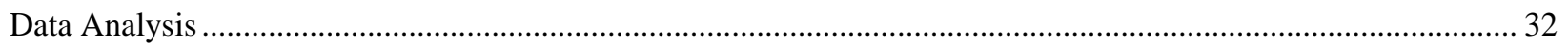

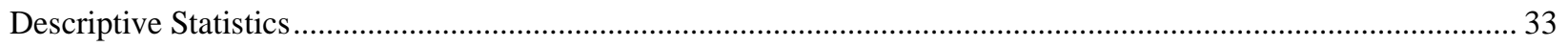

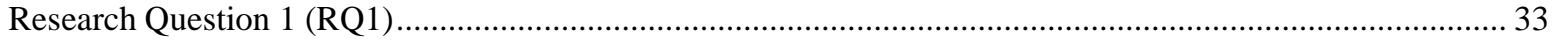

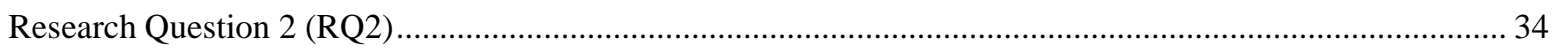


RQ1: What do K-12 teachers perceive to be the benefits and disadvantages in using social media for professional development?

1a. What value do K-12 teachers see in using social media for professional development? 38

1b: What concerns do K-12 teachers have about using social media for professional development?..... 1c: In what ways do teachers feel self-determined professional development practices obtained through social media impact teaching practices?

RQ2: In what ways do K-12 teachers use social media for self-determined professional development?

2b. How often do teachers as self-determined learners use social media for professional development? ........ 46

Summary

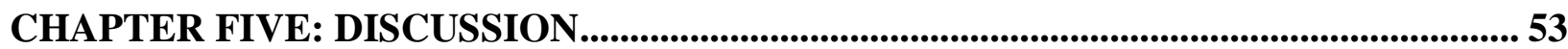

Implications for Professional Development Providers 


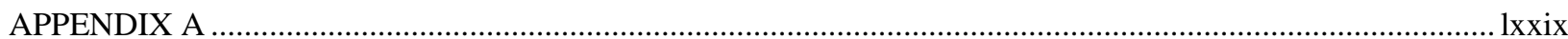

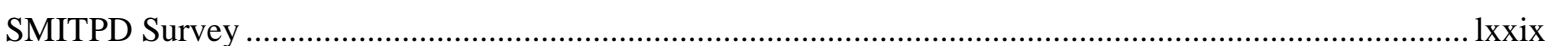

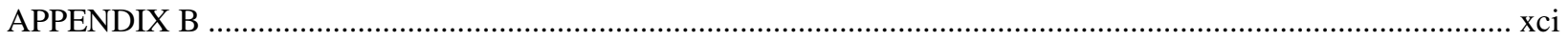

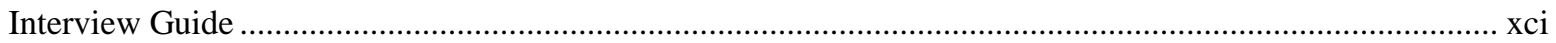

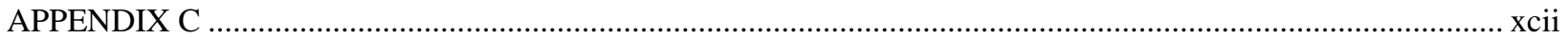

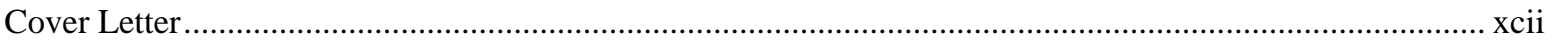

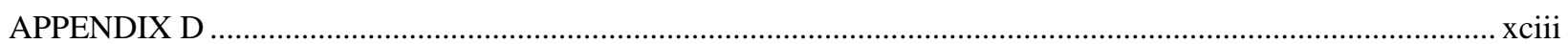

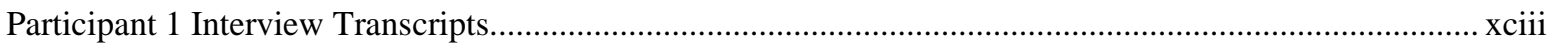

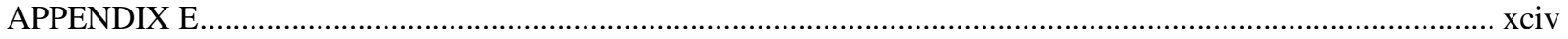

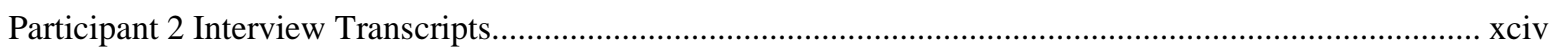

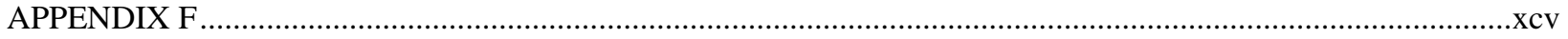

Participant 3 Interview Transcripts.............................................................................................................

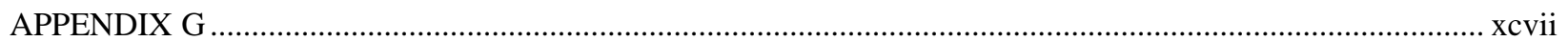

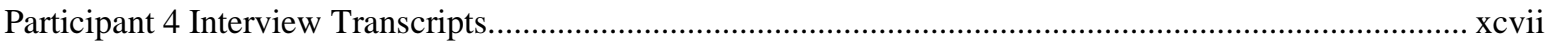

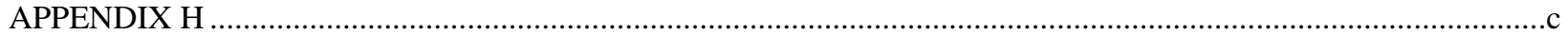

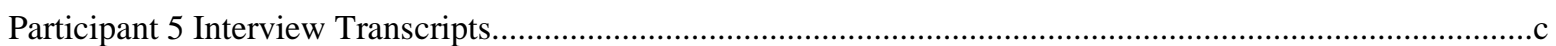




\section{Tables}

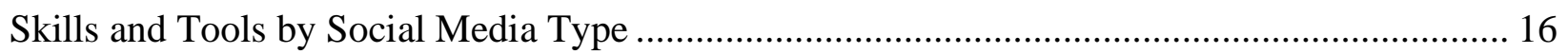

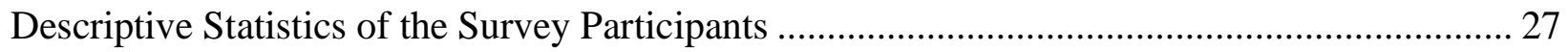

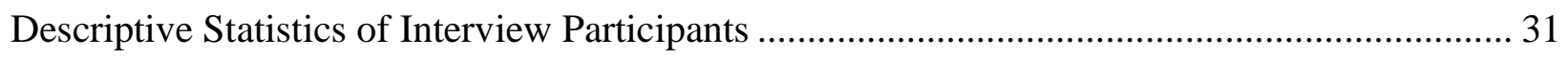

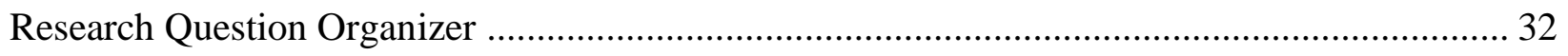

Thematic Categories and Research Question Correlation ............................................................ 36

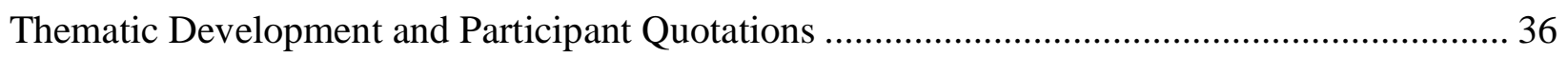

Perceived Value of Using Social Media for Professional Development ..................................... 39

Triangulation of Quantitative and Qualitative Data................................................................. 50

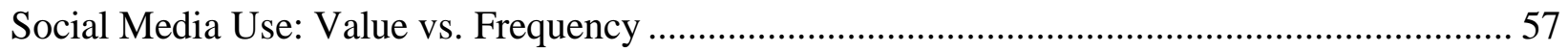

\section{Figures}

Continuum of Characteristics: Pedagogy, Andragogy, Heutagogy ............................................. 10

SMITPD Survey: Perceived Value of Social Media Activities ....................................................... 38

SMITPD Survey: Level of Concerns with Using Social Media .................................................. 41

SMITPD Survey: New Knowledge/Learning Gained ................................................................. 43

SMITPD Survey: Frequency of Social Media Access by Device ……........................................ 45

SMITPD Survey: Frequency of Social Media Use for Professional Development Activities ..... 46

SMITPD Survey: Frequency of Social Media Platform Use ..................................................... 47 


\section{Chapter One: Introduction}

\section{Background for Study}

We are in an age with highly open access to knowledge, skills, and competencies. Due to a complex modern workforce, individuals must have the ability to quickly adjust to new innovations, and continuously obtain new skills (Blaschke, 2014). The ability to manage one's own learning is an essential skill for lifelong learners in the workforce (Canning, 2010).

In an andragogical learning design, learners assume responsibility for learning, and receive guidance from an instructor. Guidance from an instructor could include diagnosis of learning needs, formulation of learning goals, identification of resources, selection of appropriate learning strategies, and/or evaluation of learning outcomes. A heutagogical, self-determined approach, follows the andragogical design, however, without guidance (Hase, 2009). When individuals choose their own learning path, it typically results in a nonlinear format (Peters, 2002).

Heutagogy has been defined as the study of self-determined learning (Hase \& Kenyon, 2000). Heutagogy focuses on the process of learning rather than learning content, allowing learners the opportunity to make sense of the content (Hase \& Kenyon, 2001). While heutagogy focuses on the process of learning, content remains very important; heutagogy examines how individuals learn and apply content.

In a rapidly evolving, innovative society, new skills must be adopted by learners and leaders. As in other professions, teachers must practice lifelong learning in their subject areas and pursue continuing professional development in order to maintain effectiveness. Heutagogy offers a teaching and learning framework for navigating the frequent changes in curriculum, assessment modalities, technologies, and economic realities that affect the teaching and learning environment. Heutagogy can inform practices, especially in the informal learning context (Hase, 2009). 
Approaches informed by heutagogy can increase professional development opportunities for teachers.

While the current educational system attempts to produce competent students, it fails to realize human potential. Identifying human potential through learning involves discovering ways for learners to explore, discover, test hypotheses, research, reflect, create, change, analyze, and synthesize; heutagogy places an emphasis on these activities in both formal and nonformal learning environments (Hase, 2014). Hase (2014) describes the skills needed by today's learners in the workforce, and those needed by the teachers who are meant to educate them. He redefines the role of the teacher as one of learning leader, who is equipped with attributes and skills that enable him or her to manage change, stimulate engagement, learn, and use open systems thinking.

Professional development programs "are systematic efforts to bring about change in the classroom practices of teachers, in their attitudes and beliefs, and in the learning outcomes of students" (Guskey, 2002, p. 381). Research has shown little visible change in teaching practice from current professional development programs, indicating the need for another solution (Huberman, 1995; Richardson, 1990). From 1986 to 2006, in general, professional workers' feelings of independence in their work fell from $72 \%$ to $38 \%$ (Chakrabortty, 2011, para. 11). In education, this time period has created a culture of compliance. Lessons plans are to be created according to a political blueprint, and teaching constrained by the requirements. Professional learning has become a means for reinforcing these limitations (Price, 2014 p.108).

Small-scale studies (Beames, 2004; Hawkes, 1999; Hunter, 2002; Stuckey, 2004) suggest that online social media platforms play an influential role in generating self-sustainable growth and development; these environments support the development of learner-generated content, and allow learners to be self-directed in their learning path. The interactive nature of social media gives 
social researchers the opportunity to look at the ways people use these applications, and how they influence connections and social theories (Wang et al., 2007; Yoo, 2010). This also provides educational researchers a way to extend andragogical approaches to professional development for teachers.

\section{Rationale for Study}

The most prominent agent of change is personal motivation (Borko \& Putnam, 1995; Richardson, 1990), rather than external factors, such as organizational requirements. Research indicates that most people learn more during their regular daily activities than in formal settings (Merriam 2007).

Teaching and learning environments undergo frequent changes in curricula, assessment modalities, technologies, and economic realities. Educational researchers claim that current education programs do not encourage the development of new skills, nor do they have any longterm effect on teaching practices (Boyle, While, \& Boyle, 2004; Guskey, 2002; Huberman, 2001). Teaching strategies and competences must evolve to empower 21 st-century learners (Caena \& Redecker, 2019). The Assessment and Teaching of Twenty-First Century Skills (ATC21S) framework (Binkley et al., 2012) is an international project consortium aimed to promote education reform. This framework proposes the need for substantial shifts in teaching/learning processes, as well as the assessment of learning (Griffin et al., 2012). Thus, an alternative approach that focuses on effective professional development is needed create the significant change in teacher practices. The alternative investigated in this dissertation is heutagogical practices within online social media networks. 


\section{Research Focus and Research Questions}

The purpose of this study was to understand how teachers use heutagogical practices in online social media networks, and determine if these practices can provide meaningful professional development opportunities. In particular, it aims to develop a better understanding of how selfdetermined learning via social media networks impacts teaching practices, as well as determine what teachers perceive to be the benefits and disadvantages in using social media for selfdetermined professional development. The purpose of the study described in this dissertation is:

To investigate heutagogical practices within online social media networks as a source of teacher professional development.

The specific Research Questions of this study:

1. What do K-12 teachers perceive to be the benefits and disadvantages in using social media for professional development?

a. What value do K-12 teachers see in using social media for professional development?

b. What concerns do K-12 teachers have about using social media for professional development?

c. In what ways do self-determined professional development practices obtained through social media impact teaching practices?

2. In what ways do K-12 teachers use social media for self-determined professional development?

a. How do teachers as self-determined learners use social media for professional development?

b. How often do teachers as self-determined learners use social media for professional development? 
c. Why do teachers as self-determined learners use social media for professional development?

\section{Description of Sections}

\section{Literature Review}

This literature review defines heutagogy and self-determined learning, then provides a depiction of the current teacher professional development landscape, followed by a description of social media. That is, (a) heutagogy, (b) professional development, and (c) social media. It also provides a conceptual framework that will inform the findings of the study and direct the methodology design.

\section{Method}

This study uses a mixed methods research design. Mixed methods studies combine qualitative and quantitative approaches within different phases of the research process (Tashakkori \& Teddlie, 1998). A researcher-created survey was used to collect the quantitative data for this study. The researcher then conducted individual participant interviews virtually, which provided qualitative data.

\section{Proposed Publication}

The content of this study aligns with the aim/scope of multiple education journals. The Journal of Computer Assisted Learning aims to make learning experiences accessible; this journal covers all uses of information and communication technology used for education. Research in Learning Technology is published by the Association for Learning Technology, and aims to promote research in the field of learning technology from online learning to social media. Teacher Learning and Professional Development (TLPD) is an open-access, peer-reviewed journal concerned with the challenges and complexities of learning to teach. Professional Development in Education is a fully refereed international journal that publishes original contributions about 
continuing professional development in its widest sense. While there are many relevant journals for this study, these journals are especially fitting. 


\section{Chapter Two: Literature Review}

This literature review defines heutagogy and self-determined learning, then provides a depiction of the current teacher professional development landscape, followed by a description of and definition of social media. That is, (a) heutagogy, (b) professional development, and (c) social media. It also provides a conceptual framework that will inform the findings of the study and direct the methodology design.

\section{Heutagogy}

Advances in technology and neuroscience, as well as a demand for improvements in education and professional development, have created a need for considering new pedagogical approaches. The concept of heutagogy offers a response to these demands (Blaschke, 2016). This

review of literature begins by defining heutagogy and the foundational theories from which it is constructed. This is followed by a description of the self-determination theory. A detailed review of the concepts and foundations supporting heutagogical practices is included thereafter. Essential elements of a heutagogical environment are then examined, followed by an account of challenges and concerns associated with heutagogy.

\section{Heutagogy Defined}

Heutagogy (Hase 2009, 2010; Hase \& Kenyon 2000, 2003, 2007, 2013; Kenyon \& Hase, 2010) is the study of self-determined learning. Heutagogy, andragogy, and pedagogy are terms that often deter people from further exploration because they are unusual and difficult to pronounce. For this reason, many researchers prefer to use the phrase, self-determined learning, as the definition of heutagogy. This can also lead to misunderstanding, as people tend to confuse selfdetermined learning with self-directed learning. Self-directed learning is a process in which learners take responsibility, typically under the guidance of an instructor, for identifying learning 
needs, formulating learning goals, pinpointing materials and resources for learning, choosing and implementing appropriate learning strategies, and evaluating learning outcomes. (Knowles, 1975). Self-determined learning is a process in which learners take initiative for identifying learning needs, formulating learning goals, identifying learning resources, implementing problem-solving strategies, and reflecting upon the learning processes to challenge existing assumptions and increase learning capabilities (Blaschke, 2012). While self-determined and self-directed learning have similarities, the key difference is the "double-loop" learning. Beyond problem-solving, double-loop learning involves dissecting variables and questioning original concepts and processes. Reflection is a key aspect of increasing learning capabilities promised through doubleloop learning (Argyris, 1974).

\section{Self-Determination Theory}

The theory of self-determination (Deci \& Ryan, 2000) is closely related, as it describes individuals with a desire for ongoing self-development. The notion of human agency is key in both self-determination theory and heutagogy. Heutagogy encompasses similar important aspects of Deci and Ryan's theory (2000), such as learner autonomy, intrinsic and goal-setting motivation, self-regulation, and self-efficacy. Heutagogy incorporates additional principles: self-reflection and metacognition, double-loop learning, learner competency and capability, non-linear learning and teaching, and neuroscientific evidence on how individuals learn (Blaschke, 2012; Blaschke \& Hase, 2015; Hase, 2013a). While heutagogy focuses on the process of learning, content remains essential; heutagogy questions how individuals learn and apply content.

\section{Heutagogical Foundations}

The heutagogical theory draws from established learning theories, including humanism, constructivism, the complexity theory, and systems thinking. Humanism (Rogers, 1969) makes the 
point that humans are natural learners. Constructivism (Vygotsky, 1978) is based on the idea that individuals make sense of the world from their own experiences. The complexity theory (e.g., Davis and Sumara 1997; Doll 1989; Doolittle and Hicks, 2003; Lissack, 1999; Waldrop, 1992) and systems thinking (Ackoff \& Emery, 1972; Emery, 1993) acknowledge the importance of the environment and context in learning, and the complex relationship between them (Hase, 2009). The components underlying heutagogy are drawn from multiple theories, in addition to those aforementioned: phenomenology (Rogers, 1951), double loop and organizational learning (Argyris \& Schon, 1996), andragogy (Knowles, 1984), learner-managed learning (Graves, 1993; Long, 1990), action learning (Davis \& Hase, 1999; Kemmis \& McTaggart, 1998), capability (Stephenson, 1992), work-based learning (Gattegno, 1996; Hase, 1998) and knowledge management (Davenport \& Prusak, 1998), as well as the latest neuroscience. These theories take into account the influence of human social perception, subjective experience, and experiential learning and development, which are all fundamental in establishing the heutagogical theory.

Changes in the way people learn emerged in the nineteenth century; these changes were brought about by humanists, followed by constructivists. The primary purpose of humanism is to be the development of self-actualized, autonomous people (Rogers \& Freiberg, 1994). Humanism involves student-centered, personalized learning, where the educator's role is to facilitate learning. Constructivism refers to the idea that learners construct knowledge for themselves, which builds on John Dewey's concept of experiential learning.

Sociomateriality is also relevant; it is a perspective that "challenges the deeply taken-forgranted assumption that technology, work, and organizations should be conceptualized separately, and advances the view that there is an inherent inseparability between the technical and the social" (Orlikowski and Scott 2008 p. 434). It emphasizes that "material agency and human agency are so 
entangled with each other that previously taken for granted boundaries are dissolved" (Yoo 2010 pp. 221-222). As individuals interact with various digital and non-digital artifacts to perform their everyday activities, the social and material aspects of daily experiences are integrally intertwined through sociomateriality (Orlikowski 2007).

\section{Elements of Heutagogy}

Figure 1 diagrams the characteristics of pedagogy, andragogy, and heutagogy, outlining how heutagogy builds on and extends the previous theories and concepts.

\section{Figure 1}

Continuum of Characteristics: Pedagogy, Andragogy, Heutagogy

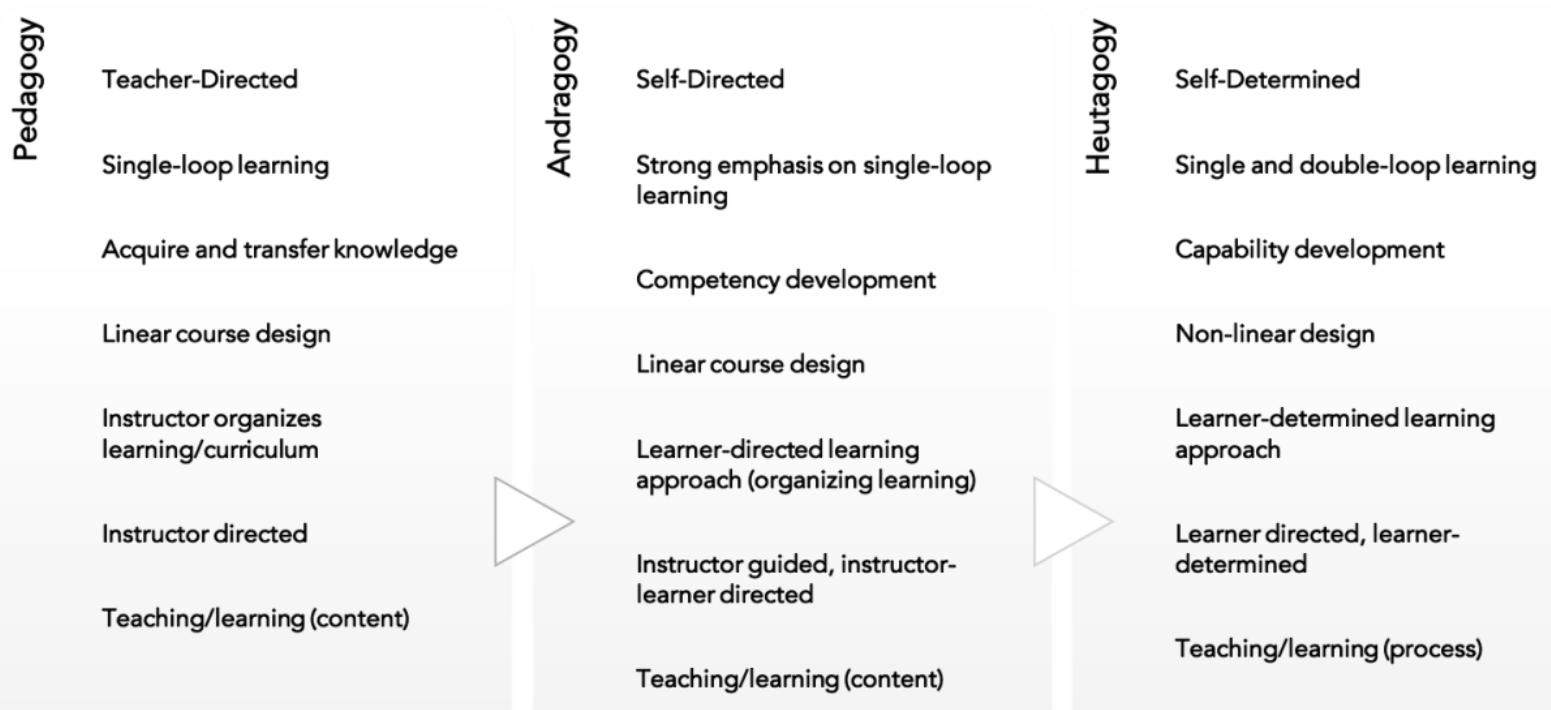

Heutagogy regards human agency to hold a significant role in behavior. Having the capacity to make choices and decisions, and act on them in the real-life situations defines human agency (Hase, 2014 p.18). However, the manner in which experiences influence decisions and actions is a very complex matter. What we are concerned with in self-determined learning is that individuals have agency with respect to how, what, and when they learn. 
It is important for self-determined learners to acquire both competencies and capabilities (Hase \& Kenyon, 2000, 2007; Stephenson, 1994 as cited in McAuliffe et al., 2008, p. 3). Competency can be described as proven ability in acquiring knowledge and skills. Capability can be defined as the learner's confidence in his or her competency, resulting in the ability to solve problems in diverse settings (Gardner, Hase, Gardner, Dunn, \& Carryer, 2007). Capable individuals exhibit self-efficacy in knowing how to learn and continuously reflect on the learning process. Holistic reflection is crucial within the heutagogical learning process. The learner must reflect not only on what he or she learned, but also on the way in which it was learned. This requires metacognition, or understanding how learning occurs, (Blaschke \& Hase, 2016) and assists the learner in developing their own learning process. Communication and teamwork skills, as well as a creative and flexible approach to competency application, have been found to be characteristics of capable individuals (Gardner et al., 2007; Hase \& Kenyon, 2000; Kenyon \& Hase, 2010).

Heutagogy employs a double-loop learning process. When an error is detected and corrected without a systematic or process change, it uses a single-loop approach. This type of process is most often utilized when components (goals, values, plans, rules, etc.) of a system are operationalized. Double-loop learning occurs when an error is detected and corrected in ways that involve modifications of normal components, such as policies or objectives (Argyris, 1977). Learners consider the problem, resulting actions and outcomes, and then reflect on the problemsolving process and how it influences their beliefs and actions (Hase \& Kenyon, 2000). The double-loop learning process occurs when learners question and test their personal values and assumptions to enrich how they learn (Hase, 2009). 


\section{Heutagogy Challenges}

Heutagogy challenges the idea that content is the core of learning, especially in an era where content is easily accessible to everyone (Blaschke \& Hase, 2015). Heutagogy confronts many of the assumptions underpinning formal education. Hase (2009) and Hase and Kenyon (2013) believe that learning does not fit into the definition of a change in behavior; they reason that learning goes beyond acquiring competencies (knowledge and skills) to a conceptual level of understanding the world, possibly a profound experience. It is impossible for a teacher to know what changes have occurred in a person's brain when they have truly learned something, which leads to back to the previously section on brain research. Based on the learner's experience and new understanding, he/she will deliberate a whole new set of questions. The set curriculum is at risk of becoming largely irrelevant to the new needs of the learner. However, teaching has become invariable. There is no room for negotiated learning, as the curriculum and universal assessment dictate teaching.

Obstacles in applying the heutagogical model include factors related to facilitation, institutional culture, time, and assessment. Facilitation and culture concern an academic institution's approach and design for online education. Not every institution's learning culture is conducive to the heutagogical approach. Online educators must assess their ability to use heutagogy in distance learning settings, as well as assess the institutional culture surrounding teaching and learning in this model. A mindset of educators being teachers in a traditional environment provides another obstacle, as many educators feel forced into traditional methods of teaching (Horn \& Little, 2010). 


\section{Teacher Professional Development}

Heutagogy can be viewed as an attempt to contest some of the traditional concepts concerning teaching and learning that still prevail in teacher-centered learning; it stresses the importance of knowing how to learn as a fundamental skill, which could ultimately change the way we look at professional development. This section reviews literature that defines professional development, and looks at professional development frameworks, constituents, and challenges.

\section{Professional Development Defined}

Teaching is a multifaceted process, which requires extensive knowledge in a variety of areas, as well as the competence to integrate and apply this knowledge to a variety of settings, under different conditions, and with a diverse population of students (Hollins, 2011).

The continual deepening of knowledge and skills is an integral part of the development of professionals in all fields. It is important for professional environmental conditions to support the rapid acquisition of new knowledge and skills. Teachers must maintain up-to-date knowledge of the subject area(s) they teach (National Board for Professional Teaching Standards, 1989; Shulman \& Sparks, 1992). Studies have shown that student achievement relies predominantly on teacher quality (Meister, 2010; Opfer \& Pedder, 2011).

Teacher professional development is a major focus of systemic reform initiatives (Corcoran, 1995; Corcoran et al., 1998). According to the Department for Education and Skills (2001), the professional growth of teachers is at the heart of transforming the education system. Traditional approaches to professional development, such as short workshops or conference attendance, do not appear to alter what teachers teach or how they teach (Sparks \& Hirsh, 2000). For the majority of teachers, professional development appears to still be characterized by these fragmented one-time workshops (Darling-Hammond, Hyler, \& Gardner, 2017). Modern 
approaches to teaching are needed to develop student competencies like complex problem-solving, critical thinking, effective communication and collaboration, and self-direction. Effective professional development is needed to help teachers learn and refine the expertise required to teach these skills.

Effective professional development can be defined as professional learning that results in changes in teacher practices and improvements in student learning outcomes (Darling-Hammond, Hyler, \& Gardner, 2017). In order for professional development to be considered effective, teachers must use their new knowledge and skills, attitudes, and beliefs to improve the content of their instruction or their approach to pedagogy, or both (Desimone, 2009). Research indicates that teacher professional development is more effective when it is sustained, collaborative, content/subject specific, elicits external expertise, gains teacher input, and is practice-based (Sims \& Fletcher-Wood, 2021).

Twenty-first century competences are necessary to navigate living in the present and future, which are greatly shaped by technology that changes workplaces and lifestyles (Caena \& Redecker, 2019). These competences highlight new skills, but also place new emphasis on old ones, thus equipping individuals for new ways of thinking and working, as outlined in the Assessment and Teaching of Twenty-First Century Skills (ATC21S) framework (Binkley et al., 2012). ATC21S is an international project consortium involving academic institutions, policymakers, and technology businesses, coordinated by the University of Melbourne; the project aimed to promote education assessment reform to directly impact teaching and learning 21 stcentury skills (Griffin, Care, \& McGaw, 2012). 


\section{Professional Development Challenges}

The contemporary educational environment presents many challenges to teachers. Technological changes and a society marked by increasing global connectivity requires that today's teachers be empathetic problem solvers capable of recognizing and weighing diverse perspectives (Boix Mansilla \& Jackson, 2013; Reimers \& Chung, 2016; Wagner et al., 2010). Teaching strategies need to change, as well as the competences teachers need to develop to empower 21 stcentury learners.

Making tacit knowledge explicit (Eraut, 2000) presents a challenge, especially for the evaluation of learning. Another challenge is found in the insufficient structural and social supports (Louis \& Kruse, 1995), and the urgency of the multiple tasks teachers are apportioned (Kennedy, 2005; Little, 2003b). It may become difficult for teachers to consistently provide high-quality instruction, produce new thoughts and solutions to teaching challenges, or cultivate instructional innovation with such barriers and limitations in place. Because the professional development mandated by schools often uses generalized approaches, it can lack support of individual educators' needs and interests. The shortcomings of traditional professional development have left many educators with a lack of engagement in professional learning activities outside official and required programs.

\section{Social Media}

Social media have been designed using the technology platform known as Web 2.0. Kaplan \& Haenlein (2010) defined social media as a "group of Internet-based applications that build on the ideological and technological foundations of Web 2.0, and that allow the creation and exchange of User Generated Content" (p. 61). While multiple definitions exist among researchers, most revolve around the notion that social media is a technology network tool that supports collaborative 
communication (Anderson, 2005; Bates \& Sangra, 2011; Tadros, 2011). It is the user-centered aspect of social media that makes it well-suited for teaching and learning (Blaschke \& Brindley, 2014). This section of text explores the benefits of social media in relation to learning, and discusses the social media classifications used in this study. In addition, user capabilities, specific social media platforms, current uses, and challenges are examined.

Prensky’s (2010) framework adapted to a social media classification scheme from Kaplan and Haenlein (2010) contributed to the classifications, skills, and tools relevant to this study, displayed in Table 1. Categories of social media are used to classify various social media tools, which were then matched to the critical learning skills that these are best suited to support. The skills were identified based on the literature reviewed for this study.

\section{Table 1}

Skills and Tools by Social Media Type

\begin{tabular}{|c|c|c|}
\hline Classification & Skills & Tools \\
\hline Social Networking & $\begin{array}{l}\text { The ability to: communicate (read, write, discuss, interact); } \\
\text { collaborate; search; explore; listen; connect; share; think } \\
\text { critically; reflect; support others; build community; promote } \\
\text { (self); authenticate the information read and shared; learn } \\
\text { and reflect on that process }\end{array}$ & $\begin{array}{l}\text { Twitter, Linkedln, } \\
\text { Facebook, and } \\
\text { social tagging (e.g., } \\
\text { Instagram, } \\
\text { Pinterest) }\end{array}$ \\
\hline $\begin{array}{l}\text { Content/information } \\
\text { sharing communities }\end{array}$ & $\begin{array}{l}\text { The ability to communicate (read, write, discuss, interact); } \\
\text { collaborate; search; inquire; compare; combine; think } \\
\text { critically; reflect; observe; share; build community; promote } \\
\text { (self); distribute; authenticate the information read and } \\
\text { shared; learn and reflect on that process }\end{array}$ & $\begin{array}{l}\text { YouTube, Twitter, } \\
\text { Linkedln }\end{array}$ \\
\hline
\end{tabular}

Blaschke \& Brindley, 2014; Gardner et al., 2007; Hase \& Kenyon, 2000; Kenyon \& Hase, 2010.

Social media offer a variety of pedagogical benefits and affordances. The learner-centered environment offered by social media extends the boundaries of a physical setting, giving individuals opportunities to learn from the world (Harris \& Rea, 2009). Social media's shared 
spaces provide a place for the collaborative process, and for individuals to assess their strengths and weaknesses against peers.

It has become common practice for educators to utilize social media platforms for professional development. These include Twitter (Carpenter et al., 2019; Greenhalgh \& Koehler, 2017), Facebook (Kelly \& Antonio, 2016; Lantz-Andersson et al., 2017), Instagram (Carpenter, et al., 2019), and Pinterest (Schroeder et al., 2019), as well as others.

\section{Social Media \& Self-Determined Learning}

Self-determined learning thrives in social media environments, since the responsibility for learning is in the hands of the learner (Hase \& Kenyon, 2007). Because social media has grown in popularity, researchers are interested in the relationship between learning, community, and technology (Wenger, White \& Smith, 2009). McLoughlin and Lee (2008) suggest that the design of social networking platforms support the development of the learner's ability to direct and determine their own learning. These platforms offer opportunities for learners to connect and collaborate outside of formal boundaries, and gain practical workforce experience (Coleman, 2013; Minocha, 2009). Social media represent an increasingly significant channel for informal professional development among teachers, and provide an enlightening approach for collective knowledge building (Bommel et al., 2020).

\section{Content/Information Sharing Communities}

Online communities allow learners and educators to share user-generated content, resources, and information with each other and can offer pedagogical benefits, such as supporting self-directed and inquiry-based learning, collaboration, and interaction among individuals (Conole, 2012). Information-sharing communities can also be used to distribute a variety of 
multimedia, such as presentations (e.g., SlideShare), lectures (e.g., YouTube), and images (e.g., Instagram and Pinterest) and to disseminate these using different channels (Conole, 2012).

Educators have used social media as a professional tool to establish communities of practice (e.g., Goodyear et al., 2014; Qi \& Wang, 2018). Communities of Practice (CoP) are groups of individuals with a common concern or a passion, who interact regularly to increase knowledge and skills of a certain practice (Wenger \& Snyder, 2000). There are also Professional Learning Communities (PLC) and Professional Learning Networks (PLN); while there are slight differences in the definitions, these terms are interchangeable for the purposes of this project. Professional Learning Communities are often described as a type of CoP utilized specifically by teachers working collaboratively to improve student achievement. Community of Practice networks have been emerging in nearly every professional sector; they incorporate several effective elements of professional development, and foster an increase in student learning. More than 25 years of research substantiates the significance of teachers' interconnected relationships as a factor in school improvement (Hubbard, Mehan, \& Stein, 2006; Little, 1982; Louis, Marks, \& Kruse, 1996; McLaughlin \& Talbert, 2001). In their large-scale, longitudinal study of school reform in Chicago, Bryk, Sebring, Allensworth, Luppescu, and Easton (2009) found that measures of professional community differentiated consistently between advancing and declining schools, and were predictive of student outcomes in reading and mathematics.

\section{Facebook}

Facebook is the most widely used Social Networking site in the world (Moshin, 2020). Sharing on Facebook affects human behavior in several capacities, such as cultural (Manca \& Ranieri, 2016), social (Boticki et al., 2015; Jong et al., 2014; Yu et al. 2010), political (Pasek et al., 2009), and professional knowledge (Hart \& Steinbrecher, 2011; Sumuer et al., 2014). Teachers 
use Facebook for a variety of reasons, such as contacting old friends, colleagues, and students or sharing thoughts, opinions, and memories. They might also keep up with social, political, cultural, and technological developments and changes in local and global environments. Teachers might also be members of Facebook groups related to teaching and learning. A considerable number of studies regarding Facebook as a teaching and/or learning environment have been conducted (Amador \& Amador, 2014; Baran, 2010; Davies, 2012; Jong et al., 2014; Pimmer et al., 2012; Sanchez et al., 2014; Yu et al., 2010). However, there are minimal studies investigating social media's impact on teacher professional development.

\section{Twitter}

Twitter often serves as a news aggregator. Users can contribute to discussions, share others' posts, and learn about new ideas and people. Many perceive the content they share on Twitter as much more professional and topic-centric than what they exchange on Facebook (Hosein, 2013). Twitter enables individuals to be constantly updated about content-specific developments about technologies. Using Twitter allows individuals to follow topics and persons of interest. Retweets, or sharing a tweet, contain the information of the creator, helping people find experts and thought leaders on a variety of topics.

\section{LinkedIn}

While LinkedIn often serves as an avenue to display a professional profile and job-search, professional communities on LinkedIn provide individuals with a sense of what other knowledge workers with similar positions or in similar organizations engaged in; this supports awareness of current trends and innovative ideas (Hosein, 2013). LinkedIn communities create ways to learn about trends happening outside an individual's local organization or school. 


\section{Benefits to Professional Development}

Social media allow educators to collaborate with colleagues beyond their local environment (Carpenter \& Green, 2017), and develop professional networks focused on their specific needs (e.g., Smith Risser, 2013). Social media create the potential for teachers to find, share, and discuss instructional resources. Studies of educators' social media activities show multiple benefits to professional development (Carpenter \& Harvey, 2019). Social media can provide immediate value to teachers by counterbalancing the isolation they often feel in their classrooms (Duncan-Howell, 2010; Gray, 2004; Hur \& Brush, 2009; Vavasseur \& MacGregor, 2008). Beyond the immediate value that teachers find through their engagement with colleagues in an online community, teachers can gain curriculum-based knowledge and enhanced selfefficacy with respect to implementing technology (Vavasseur \& MacGregor, 2008). Storytelling and the development of a shared collection of stories and cases can function as a vital knowledge source for members of a community (Gray, 2004). In studying the potential of online communities as a source of professional learning for teachers, Duncan-Howell (2010) was interested in knowing if teachers changed any of their teaching practices as a result of their participation in an online community. Seventy-seven percent of surveyed respondents indicated that they had been exposed to new ideas and resources that they subsequently used in the classrooms. Vavasseur and MacGregor's (2008) evaluation of the educational technology specialists at the state's educational technology center revealed that teachers' application of knowledge gained through their participation in the online community did lead to appropriate instructional applications of basic productivity, research, and communication tools that were the focus of the professional development experience. 


\section{Social Media Challenges}

Social media present challenges to conventional models of professional development. These networks devalue the notions of expertise and sources of authority. Managing knowledge also becomes a challenge. They offer the opportunity for educators to shed the mantle of compliance and reclaim their lost professional autonomy. There are intrapersonal challenges (Carpenter \& Harvey, 2019), such as internal conflicts concerning online self-representation (Kimmons \& Veletsianos, 2014). There are also interpersonal challenges, related to interactions with other individual educators. For example, teachers could find a social media post from another educator to be offensive, unprofessional, or harassing. Some professional communities might be limited because they prioritize certain preferred professional identities for teachers (Zembylas, 2018), or attract only individuals who share similar perspectives or experiences (Thelwall, 2009).

\section{Summary of Literature Review}

Heutagogy is concerned with understanding how people learn best and how the methods derived from this understanding can be applied to educational systems. The heutagogical theory draws from multiple established learning theories, and is an extension of andragogy. There is a growing body of research around the concept of heutagogy in education (Blaschke, 2012) but few examples of heutagogy exist in practice, especially as a framework for professional development. Teachers are learning leaders, and require specific skills and attributes to successfully lead others in learning. Furthering and assessing students' competences requires continual teacher professional development. The urgency of multiple tasks and requirements teachers are delegated plays a role in the flexibility and time available for professional development.

Studies show that the majority of traditional professional development programs are failing to achieve effective change in teachers. The concept of professional development is being 
drastically reframed by self-determined learning through online social networks. Self-determined learning thrives in social media environments (Blaschke, 2012). There are a variety of social networking platforms and professional communities of practice, allowing teachers to focus on specific needs.

There are minimal studies investigating the effect of social media on teacher quality and implementation of new knowledge. The purpose of this study is to understand how teachers use heutagogical practices in online social networks, and determine if these practices can provide meaningful professional development opportunities.

\section{Research Focus and Research Questions}

The purpose of this study is to understand how teachers use heutagogical practices in online social networks, and determine if these practices can provide meaningful professional development opportunities. This study aims to develop a better understanding of the effect of participation on teaching practices.

The specific aim of the study described in this dissertation is:

To investigate heutagogical practices within online Social Media as a source of teacher professional development.

The Research Questions of this study:

1. What do K-12 teachers perceive to be the benefits and disadvantages in using social media for professional development?

a. What value do K-12 teachers see in using social media for professional development?

b. What concerns do K-12 teachers have about using social media for professional development?

c. In what ways do self-determined professional development practices obtained through social media impact teaching practices? 
2. In what ways do K-12 teachers use social media for self-determined professional development?

a. How do teachers as self-determined learners use social media for professional development?

b. How often do teachers as self-determined learners use social media for professional development?

c. Why do teachers as self-determined learners use social media for professional development? 


\section{Chapter Three: Methodology}

\section{Research Design}

This study utilized a mixed method approach by combining quantitative and qualitative research techniques. According to Creswell (2005), the mixed methods research design is a process for 'collecting, analyzing, and 'mixing' both quantitative and qualitative design in a single study to understand a research problem" (p. 510). The mixed methods approach was adopted as a process to gather and integrate data collected in both qualitative and quantitative processes (Greene, Caracelli, \& Graham, 1989; Johnson \& Christensen, 2004; Reichardt \& Rallis, 1994). By combining qualitative interviews and quantitative data, the researcher is provided with the opportunity to understand the experience from the perspective of the participant (Johnson \& Onwuegbuzie, 2004; Merriam, 1998). Quantitative research seeks explanations and predictions that generalize other persons and places. The quantitative part of this study consisted of a survey, which focused on teachers' perceptions and current application of social media for professional development. In addition, qualitative data were gathered through interviews, which focused on participants' experiences, capabilities, and motivations. The interviews allowed participants to go beyond a single answer response and elaborate on personal experiences. The research questions guided the data collection of the study. The interviews were coded by content and inductive and frequency analyses were completed. Two forms of triangulation were employed: analyst (author and independent researcher) for the qualitative data; and method (survey and interview).

Volunteer response sampling was applied, as well as purposive sampling, to the population of K-12 teachers. The effort was pursued with a focus on the attributes and skills teachers exhibit within social networks, as well as their perceptions of social technologies for professional development. This study considers emerging social networking platforms, often known as social 
media or Web 2.0 (such as blogs, wikis, public social networking sites including Facebook, Twitter, and LinkedIn, as well as enterprise social networking technologies that are specifically hosted within an organization's environment). Studying this wide array of social technologies will allow for a greater understanding of the ways teachers make sense of the diverse social technologies now available to them, and therefore the ways they use these for gathering and sharing knowledge.

\section{Description of Setting}

This study took place electronically using social networking tools. Specifically, Facebook Twitter, LinkedIn, and Google Forms were used to recruit participants, disseminate the survey, and collect data. These social media tools are considered social networking and content/information sharing communities.

\section{Participants}

\section{Description of participants}

Participants included teachers from eleven different states in the U.S. Participants' demographic characteristics, such as age, gender, seniority, subject area, and grade level, and geographic location were collected and are presented in Table 2. Most participants were from the researcher's home state $(\mathrm{nWV}=40,73.58 \% ; \mathrm{nTN}=3,5.66 \% ; \mathrm{nIN}=2,3.77 \%)$. As shown in Table 2, the majority of participants were from the Elementary (multi-subject), Special Education, Mathematics, and Social Studies content areas $(\mathrm{n}=16,30.19 \% ; \mathrm{n}=5,9.43 \% ; \mathrm{n}=4,7.55 \% ; \mathrm{n}=$ 4, 7.55\%), followed by Reading and Technology $(n=3,5.66 \% ; n=3,5.66 \%)$. Four participants taught in two distinct subject areas. Additionally, the mean age (41 years old) and average seniority (14 years) of participants revealed that the sample consisted of both new and experienced teachers of each age range. The gender distribution was not nearly equal (nFemale $=048 ;$ nMale $=005)$. 
Nearly 55\% of participants held a Master's Degree, while the rest had a Bachelor's Degree or Bachelor's Degree with some Master's credits $(\mathrm{nMA}=29,54.72 \%$; $\mathrm{nBA}=13,24.53 \%$; $\mathrm{nBA}+=$ 11, 20.75\%). All participants confirmed that they were current teachers and active social media users.

\section{Participant Selection Process}

The Social Media Impact on Teacher Professional Development (SMITPD) survey opportunity was announced to participants through the researcher's Facebook, LinkedIn, and Twitter pages. The researcher had approximately 60 Facebook connections with the teacher population, as well as a membership to three educational groups on Facebook. The survey was also delivered to the 60 Facebook connections through Facebook Messenger with a request to forward the message to their own teacher connections on these social media platforms. There were three direct followers from the teacher population on Twitter, and 19 teacher population network connections on LinkedIn. The online form of the survey was open access, and data were collected over 33 days using GoogleDocs. There were two main requirements for the sample selection process. Based on the aim of the research, teachers had to be currently teaching, and they had to be active social media users. Therefore, teachers who volunteered to participate in the study had to answer two basic questions and meet the criteria before they were allowed to respond to the survey items. The invitations resulted in 53 total survey participants. Twenty-one of participants indicated a willingness to also participate in a virtual interview. The participants who agreed to participate in the interview were contacted in alphabetical order. The first five participants to respond were scheduled for an interview. 


\section{Participant Demographics}

Fifty-three teachers participated in the survey study; five of them also participated in the interview. Participant details are shown in Table 2.

\section{Table 2}

Descriptive Statistics of the Survey Participants

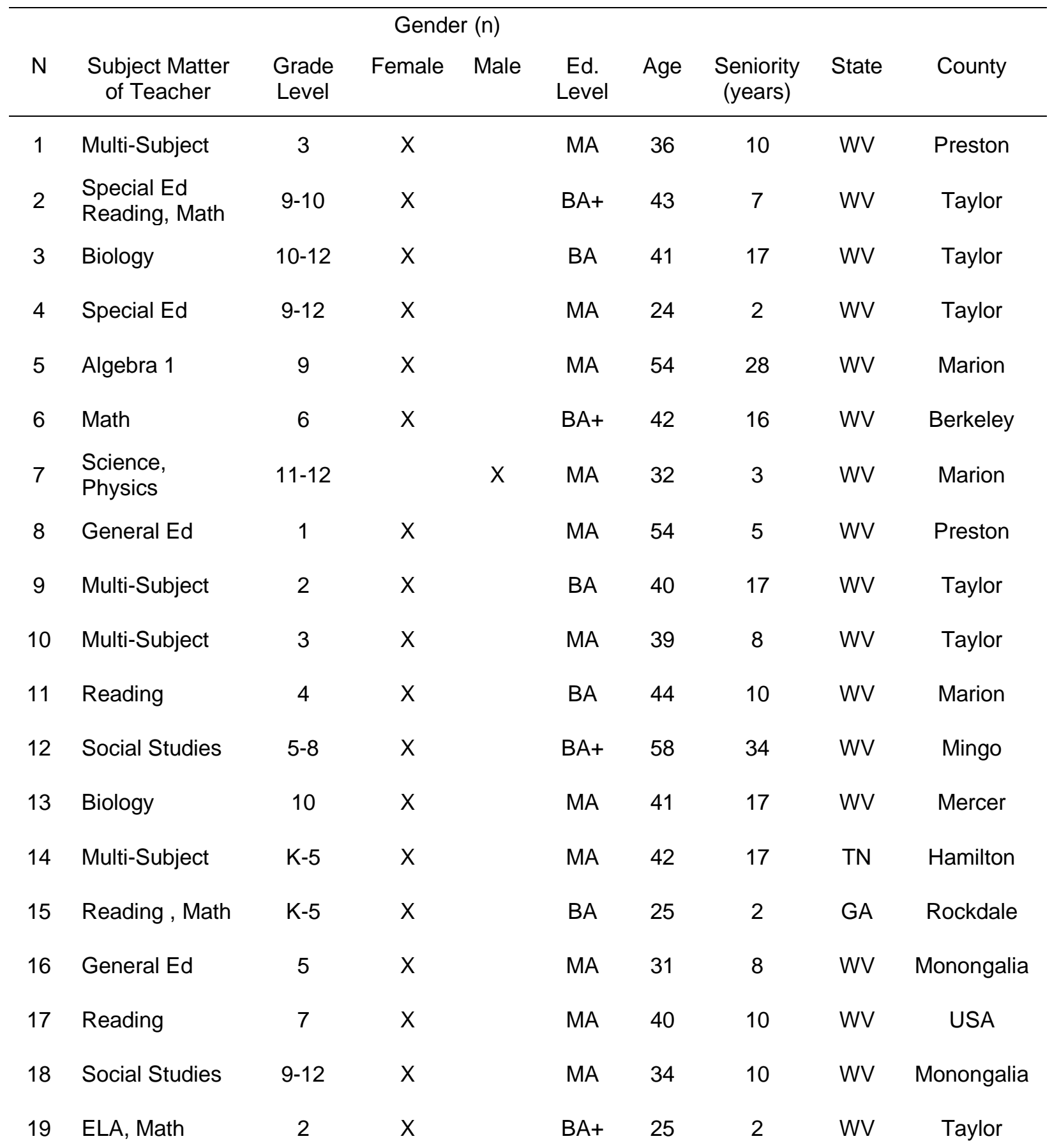


Table 2 (continued)

\begin{tabular}{|c|c|c|c|c|c|c|c|c|c|}
\hline 20 & French & $9-12$ & $x$ & & $\mathrm{BA}+$ & 36 & 14 & $\mathrm{OH}$ & Franklin \\
\hline 21 & Science & $9-12$ & $x$ & & $\mathrm{BA}+$ & 56 & 6 & WV & Kanawha \\
\hline 22 & Physical Ed & $5-8$ & & $x$ & MA & 34 & 11 & WV & Taylor \\
\hline 23 & ELA, Math & $6-8$ & $x$ & & MA & 56 & 25 & TX & Harris \\
\hline 24 & Social Studies & $5-8$ & $x$ & & $\mathrm{BA}+$ & 41 & 20 & IA & Scott \\
\hline 25 & Multi-Subject & 3 & $x$ & & MA & 59 & 38 & WV & Taylor \\
\hline 26 & Computer Ed & 8 & & $x$ & $\mathrm{BA}$ & 45 & 21 & $\mathrm{ME}$ & Mauritius \\
\hline 27 & Special Ed & 7 & $x$ & & MA & 39 & 6 & WV & Taylor \\
\hline 28 & All subjects & 4 & $x$ & & MA & 29 & 8 & IN & Marion \\
\hline 29 & Technology & $\mathrm{K}-4$ & $x$ & & MA & 43 & 20 & IN & Lake \\
\hline 30 & Special Ed & $10-12$ & $x$ & & MA & 61 & 14 & WV & Harrison \\
\hline 31 & Multi-Subject & 1 & $x$ & & $\mathrm{BA}+$ & 59 & 38 & WV & Taylor \\
\hline 32 & English & $6-8$ & $x$ & & MA & 47 & 25 & VA & Frederick \\
\hline 33 & General Ed & 3 & $x$ & & MA & 34 & 9 & WV & Pendleton \\
\hline 34 & Multi-Subject & 2 & $x$ & & $\mathrm{BA}$ & 36 & 14 & WV & Pendleton \\
\hline 35 & Math & 5 & $x$ & & MA & 27 & 5 & WV & Harrison \\
\hline 36 & $\begin{array}{l}\text { Social Studies, } \\
\text { History, } \\
\text { Current Issues }\end{array}$ & $9-12$ & & $x$ & $\mathrm{BA}+$ & 43 & 19 & PA & Washington \\
\hline 37 & Multi-Subject & 2 & $x$ & & $\mathrm{BA}$ & 40 & 11 & $\mathrm{TN}$ & Hamilton \\
\hline 38 & Multi-Subject & $\mathrm{K}$ & $x$ & & $\mathrm{BA}$ & 25 & 3 & WV & Harrison \\
\hline 39 & Choir, Theatre & $7-12$ & $x$ & & $\mathrm{BA}+$ & 54 & 30 & WV & Taylor \\
\hline 40 & $\begin{array}{l}\text { Math, Social } \\
\text { Studies }\end{array}$ & 5 & $x$ & & BA & 39 & 6 & WV & Taylor \\
\hline 41 & Multi-Subject & 5 & $x$ & & MA & 24 & 1 & WV & Harrison \\
\hline 42 & Multi-Subject & 4 & $x$ & & MA & 39 & 14 & WV & Marion \\
\hline 43 & Special Ed & $3-5$ & $x$ & & $\mathrm{BA}+$ & 43 & 21 & WV & Harrison \\
\hline
\end{tabular}




\begin{tabular}{|c|c|c|c|c|c|c|c|c|c|}
\hline 44 & Physics & $11-12$ & $x$ & & MA & 47 & 17 & IL & USA \\
\hline 45 & Literacy & 3 & $x$ & & MA & 47 & 18 & $\mathrm{TN}$ & Hamilton \\
\hline 46 & Multi-Subject & $\mathrm{K}$ & $x$ & & $\mathrm{BA}$ & 54 & 15 & WV & Harrison \\
\hline 47 & Preschool & PreK & $x$ & & $\mathrm{BA}$ & 40 & 3 & WV & Marion \\
\hline 48 & Math & $5-8$ & & $x$ & BA & 42 & 18 & WV & Taylor \\
\hline 49 & $\begin{array}{l}\text { Science, } \\
\text { Technology }\end{array}$ & $6-8$ & $x$ & & MA & 56 & 35 & WV & Ritchie \\
\hline 50 & Reading & $\mathrm{K}-1$ & $x$ & & MA & 42 & 18 & WV & Harrison \\
\hline 51 & Math & 12 & $x$ & & MA & 26 & 5 & WV & Harrison \\
\hline 52 & Multi-Subject & PreK & $x$ & & BA & 37 & 12 & WV & Taylor \\
\hline 53 & Music & PreK-5 & $x$ & & MA & 31 & 3.5 & $\mathrm{TX}$ & Hidalgo \\
\hline
\end{tabular}

\section{Data}

Data were collected for this study from December 9, 2020 through January 10, 2021. Prior to data collection, approval from the Institutional Review Board (IRB) of West Virginia University was received in December, 2020.

\section{Survey}

After reviewing several teacher-focused surveys related to social media technologies, it was realized that most were developed specifically for the given situation. Therefore, the researcher developed the SMITPD survey (APPENDIX A) using standard social media survey questions applicable to this study. One particular example developed by Hunter and Hall (2018) provided a good basis for the survey, as it was developed to examine patterns of social network application use among K-12 teachers in the United States. While the survey was designed to help understand how educational professionals use interactive and social media online technology tools to help their students, it provided an excellent structure to be modified for understanding how teachers use social media tools for professional development. The SMITPD survey questions were 
designed to lead to an understanding the participants' attitudes and perceptions of social media, specifically for professional development. Elements of heutagogy are embedded within the questions to help determine if participants employ heutagogical concepts within learning that takes place in social media environments. After the survey was developed, face validity for the survey was performed by using three doctoral-level education professionals to answer the questions and give feedback on whether the survey measured what it was intended to measure. This was used as a test-run before the survey was distributed; feedback from this group allowed for revision of the survey before distributing it to others for data collection.

Survey data collection procedure. The survey opportunity was announced as a general post, along with the survey link, on three platforms: Facebook, Twitter, and LinkedIn. The opportunity was also sent to known teachers using Facebook Messenger. The survey began with an informed consent page that was approved by the West Virginia University institutional review board. The survey was comprised of eight total sections. The first section included an explanation of the aims of the survey, as well as informed consent. This was followed by two participation questions to determine if the participant met the criteria needed for the study, criteria being that participants needed to be a current teacher and actively use one or more social media sites.

Section four contained questions about participants' demographic characteristics, such as location, subject branches, gender, age, and seniority. Section five, social media, included ten questions designed to gather information about the different kinds of online social media tools teachers use, as well as attitudes and perception. Section six contained six questions to gather information directly related to professional development. Lastly, participants were asked to indicate whether or not they would be willing to participate in a virtual interview concerning the subject matter of the survey. 


\section{Interviews}

Interview data collection procedure. Survey participants who agreed to an interview were sent an email to schedule the interview date and time. The participants who agreed to participate in the interview were contacted in alphabetical order. The first five participants to respond were scheduled for an interview. The participants were sent a Zoom invite. Zoom is a web-based video conferencing tool with a local, desktop client and a mobile app that allows users to meet online, with or without video. Due to this year's global Covid-19 pandemic, the participants were familiar with this tool. The interviews were audio/video recorded, and later transcribed verbatim. Field Notes were taken during the interviews to complement the recordings. The field notes allowed the researcher to maintain and comment on impressions, contexts, behaviors, and nonverbal cues that were not captured through the recording; these were handwritten in a notebook at the same time the interviews took place. The questions asked to participants were an extension of the survey. The researcher used the Interview Guide, Appendix B, to pursue explanations for participants' survey responses. There were five total interview participants; the demographics for these participants are shown in Table 3.

\section{Table 3}

Descriptive Statistics of Interview Participants

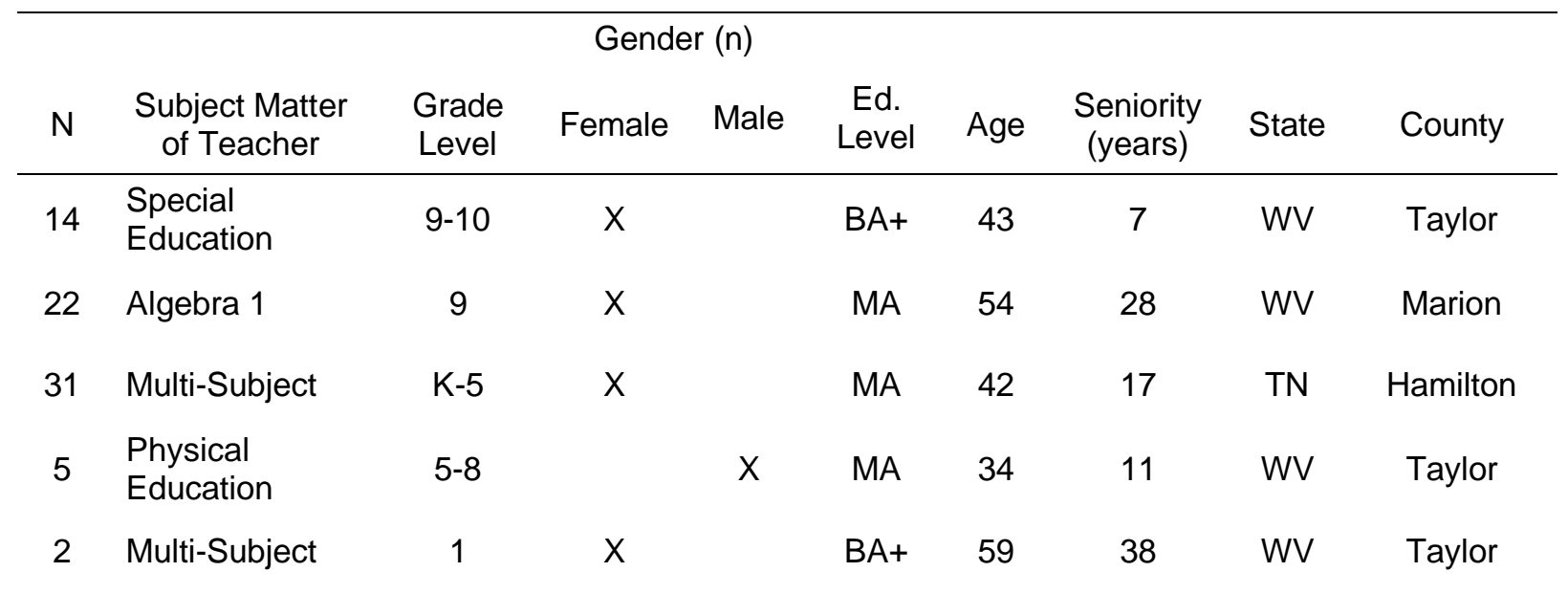




\section{Data Analysis}

Both quantitative and qualitative survey items, as well as interview questions are aligned with the corresponding research questions, displayed in table 4. The table also includes a description of the type of analysis used for each of these. The numbers displayed in parenthesis indicate the survey or interview question number(s).

\section{Table 4}

Research Question Organizer

\begin{tabular}{|c|c|c|}
\hline$R Q$ & Data & Analysis \\
\hline \multirow{3}{*}{$\begin{array}{l}\text { 1a:What perceived value do teachers } \\
\text { see in social media for professional } \\
\text { development }\end{array}$} & Interview (1) & Theme Constructing \\
\hline & Survey items close-ended $(12,22,23)$ & Descriptive Statistics \\
\hline & Survey items open-ended (13) & Theme Constructing \\
\hline $\begin{array}{l}1 \mathrm{~b} \text { : What concerns do } \mathrm{K}-12 \text { teachers } \\
\text { have about using social media for } \\
\text { professional development? }\end{array}$ & Survey items close-ended (15) & Descriptive Statistics \\
\hline \multirow{2}{*}{$\begin{array}{l}\text { 1c: In what ways do teachers feel self- } \\
\text { determined professional development } \\
\text { obtained through social media impact } \\
\text { teaching practices }\end{array}$} & Interview $(1,2)$ & Theme Constructing \\
\hline & Survey items close-ended $(14,16,17)$ & Descriptive Statistics \\
\hline \multirow{3}{*}{$\begin{array}{l}\text { 2a: How do teachers as self- } \\
\text { determined learners use social media } \\
\text { for professional development? }\end{array}$} & Interview (3) & Theme Constructing \\
\hline & Survey items close-ended $(18,20,22)$ & Theme Constructing \\
\hline & Survey items open-ended (21) & Descriptive Statistics \\
\hline \multirow{3}{*}{$\begin{array}{l}\text { 2b: How often do teachers as self- } \\
\text { determined learners use social media } \\
\text { for professional development? }\end{array}$} & Interview (3) & Theme Constructing \\
\hline & Survey items close-ended $(18,20)$ & Descriptive Statistics \\
\hline & Survey items open-ended $(19,21)$ & Theme Constructing \\
\hline \multirow{2}{*}{$\begin{array}{l}\text { 2c: Why do teachers as self- } \\
\text { determined learners use social media } \\
\text { for professional development? }\end{array}$} & Interview (1-4) & Theme Constructing \\
\hline & Survey items close-ended $(23,24)$ & Descriptive Statistics \\
\hline
\end{tabular}




\section{Descriptive Statistics}

The survey data were prepared, where the aim was to convert the raw data into something meaningful and readable. A portion of this preparation was data validation, to ensure the data collection was done as per scholarly standards and without any bias. The survey qualification questions eliminated respondents who failed to meet the research criteria. The survey settings required responses for all questions. Once in an excel spreadsheet format, the researcher conducted basic data checks, checked for outliers, and edited the raw research data to identify and clear out any data points that may interfere with the accuracy of the results. Descriptive statistics/analysis was used to summarize the data. Survey responses were grouped and assigned values.

\section{Research Question 1 (RQ1)}

Teachers' perceived value of social media for professional development was partially measured using close-ended survey questions 12, 22, and 23. Interview question 1 also contributed data towards perceived value. The relationship of survey and interview questions to the research questions appears in table 4. Teacher concerns with using social media for professional development were measured using five-point Likert-type scale statements ranging from no concern (1), to extremely concerned (5). The impact of professional development gained through social media was evaluated using close-ended survey items 14,16 , and 17. Survey question 14 collected ratings of agreement for three statements related to the impact of social media, from strongly disagree (1), to strongly agree (5). Survey questions 16 and 17 were gave yes and no options for questions directly related to the impact of social media on teaching practice and student learning. Interview question 1 provided a deeper, more specific response relating to the impact of social media on the participant's teaching practice. In addition, interview question 2 collected examples 
of social media experiences and learnings that resulted in changes or improvement to teaching practices, and student learning.

\section{Research Question 2 (RQ2)}

Participants responded to three Likert-type scale questions to indicate how they use social media for professional development. Survey question 18 listed ten beneficial ways social media can be used for professional development; participants rated each statement using a scale selection including never, rarely, sometimes, often, and all the time. Interview question 3 collected specific uses and frequencies directly correlated to survey question 18. The previous Likert-type scale was used in number 20 to determine the specific applications that are used by participants; interview question 3 was used to support these answers as well. Again, using the same scale, survey question 22 was designed to understand how participants access social media. The frequency in which selfdetermined learners use social media for professional development was also able to be measured using questions 18 and 20. To contribute to understanding why teachers use social media for professional development, survey questions 23 and 24 used Likert-type scales to determine what percentage of teachers' new knowledge, plans, ideas, etc. are gained from formal professional development activities, and what percentage is obtained through social media. A culmination of interview questions, 1-4, provided additional data in relation to research question $2 \mathrm{c}$.

\section{Themes Constructing}

Broad ideas, concepts, behaviors, and phrases were identified in the open-ended survey and interview questions. Once the data were coded, the researcher identified themes, looking for the most common responses to questions, identifying data or patterns to answer research questions, and find areas to be explored further. Both content and narrative analyses were employed. 
The open-ended data from the survey and the interviews were prepared for analysis according to themes based on the theoretical propositions discussed in the literature review. The process of data analysis began during the interview data collection, by thoughtfully facilitating the discussion and generating rich data from the interview, complementing them with the observational notes. This was followed by listening to the recordings, transcribing the interviews, reading the transcripts several times, and reading the observational notes taken during interview and summary notes written immediately after the interview. All data were organized and tabulated in alignment with the research questions.

Coding, or transforming the data into a corrected, ordered, and simplified form reduced the data size for more efficient analysis. During the open-coding process of the interview data, words, events, or phrases that were similar were put into the same category. The researcher identified seventeen working codes used to categorize the data. After the initial open-coding process, a more analytical coding of the open-ended survey and interview data began, where the researcher reexamined the categories identified to determine a relationship. The data were reduced to six main categories during the axial coding. The themes were used to gain an in-depth understanding of teachers' viewpoints concerning social media for professional development.

Table 5 outlines the themes and their relationships to the central and sub research questions. Table 6 provides selected quotes from participants, which aided in theme development. 


\section{Table 5}

Thematic Categories and Research Question Correlation

\begin{tabular}{|c|c|c|}
\hline Research Question (RQ) & Main Theme/Category & Sub-Category \\
\hline $\begin{array}{l}\text { 1b: What concerns do } \mathrm{K}-12 \text { teachers have about using } \\
\text { social media for professional development? }\end{array}$ & Concerns & \\
\hline \multirow{2}{*}{$\begin{array}{l}\text { 2c: Why do teachers as self-determined learners use social } \\
\text { media for professional development? }\end{array}$} & Motivation & \\
\hline & Emotional Support & \\
\hline $\begin{array}{l}\text { 1c: In what ways do teachers feel self-determined } \\
\text { professional development obtained through social media } \\
\text { impact teaching practices }\end{array}$ & $\begin{array}{l}\text { Formal Professional } \\
\text { Development }\end{array}$ & \\
\hline \multicolumn{3}{|l|}{$\begin{array}{l}\text { 2a: How do teachers as self-determined learners use social } \\
\text { media for professional development? }\end{array}$} \\
\hline \multicolumn{3}{|l|}{$\begin{array}{l}\text { 2c: Why do teachers as self-determined learners use social } \\
\text { media for professional development? }\end{array}$} \\
\hline $\begin{array}{l}\text { 1a:What perceived value do teachers see in social media } \\
\text { for professional development } \\
\text { 2a. How teachers use social media }\end{array}$ & $\begin{array}{l}\text { Self-Determined } \\
\text { Learning }\end{array}$ & $\begin{array}{l}\text { Connect: Share } \\
\text { Learn } \\
\text { Resources } \\
\text { Search }\end{array}$ \\
\hline \multicolumn{3}{|l|}{$\begin{array}{l}\text { 2b: How often do teachers as self-determined learners use } \\
\text { social media for professional development? }\end{array}$} \\
\hline \multicolumn{3}{|l|}{ 2c. Why teachers use social media } \\
\hline \multirow{2}{*}{$\begin{array}{l}\text { 2a. How teachers use social media } \\
\text { 2b. How often teachers use social media }\end{array}$} & & \\
\hline & Social Media Platforms & $\begin{array}{l}\text { Facebook } \\
\text { Twitter } \\
\text { Pinterest } \\
\text { YouTube } \\
\text { Instagram } \\
\text { Other }\end{array}$ \\
\hline
\end{tabular}

\section{Table 6}

Thematic Development and Participant Quotations

\begin{tabular}{ll}
\hline Theme & Participant Quotes \\
\hline Concerns & "I can't post anything on Facebook during school time" (P4, Appendix G). \\
& "I don't use Facebook that much because sometimes I find, you know whatever hot \\
button topic is happening, it becomes a forum for a lot of drama sometimes and versus \\
like actual sharing" (P2, Appendix E). \\
"I can't pull Facebook up on my computer when I'm at school" (P5, Appendix H).
\end{tabular}


Table 6 (continued)

\begin{tabular}{|c|c|}
\hline $\begin{array}{l}\text { Formal } \\
\text { Professional } \\
\text { Development }\end{array}$ & $\begin{array}{l}\text { "I took a professional development class to renew my teaching certificate" (P2, } \\
\text { Appendix E). } \\
\text { "I do webinars, because that's just something you can you know you can do and do it } \\
\text { from the comfort of your own home, especially right now" (P2, Appendix E). } \\
\text { "In professional development, I do lots of webinars off of social media" (P3, Appendix } \\
\text { F). }\end{array}$ \\
\hline \multicolumn{2}{|c|}{ Self-Determined Learning: } \\
\hline Connect: & $\begin{array}{l}\text { "So, the top three would definitely be connect with professional leaders in the field, } \\
\text { not local. I know that I usually use it to connect with people who are not local, but still } \\
\text { teaching the same curriculum that we are" (P4, Appendix G). } \\
\text { "I've reached out on social media and said, hey, somebody give me some ideas on } \\
\text { how I could create a PDE around this" (P4, Appendix G). } \\
\text { "You're connecting with other people across the United States that you don't } \\
\text { necessarily know but you can learn from their experiences" (P2, Appendix E). }\end{array}$ \\
\hline Share & $\begin{array}{l}\text { "Advanced placement classes as AP classes, those Facebook groups are all about in } \\
\text { other teachers or other coordinators sharing information" (P5, Appendix } \mathrm{H} \text { ). }\end{array}$ \\
\hline Learn & $\begin{array}{l}\text { "I've really got a lot of good ideas, too, you know, different content, things that we can } \\
\text { see different ways how we can teach" (P2, Appendix E). }\end{array}$ \\
\hline Resources & $\begin{array}{l}\text { "We adopted a new curriculum this year using expeditionary learning, and the } \\
\text { resources on Facebook alone have saved my life as far as the implementation } \\
\text { process" (P1, Appendix D). } \\
\text { "So, I've gone to Teachers Pay Teachers and I found actual resources where, you } \\
\text { know, there are high school teachers teaching algebra that already have an entire } \\
\text { unit that's designed for special ed kids and interactive and so it takes a lot of work, } \\
\text { away from my, my job" (P5, Appendix H). }\end{array}$ \\
\hline Search & $\begin{array}{l}\text { "...pick their brains about the intricacies of it, like how do we do skills block and how } \\
\text { do we pull small groups and what about the assessments..." (P1, Appendix D). } \\
\text { "if you can't find the answer, go to open up resources and somebody will be there that } \\
\text { will be able to answer for you" (P1, Appendix } \mathrm{D}) \text {. } \\
\text { "I was looking and searching for best practices and ideas" (P2, Appendix E). }\end{array}$ \\
\hline \multicolumn{2}{|c|}{ Social Media Platforms } \\
\hline Facebook & $\begin{array}{l}\text { "Facebook is really the only social media I use for education purposes" (P1, Appendix } \\
\text { D). }\end{array}$ \\
\hline Instagram & $\begin{array}{l}\text { "I'Il look at Instagram. But it's nothing like I've never found anything for teaching } \\
\text { purposes on Instagram" (P5, Appendix H). }\end{array}$ \\
\hline Pinterest & $\begin{array}{l}\text { "Number two is Pinterest shocker Pinterest I use a little bit differently, it's more of } \\
\text { like my resource page. So, if I'm if I've got a certain content that I need to present } \\
\text { for that week. I'll go to Pinterest and I'll look up ideas to make it creative and more } \\
\text { engaging" (P5, Appendix H). }\end{array}$ \\
\hline Twitter & $\begin{array}{l}\text { "I think Twitter and Pinterest are probably two of the bigger one for teaching and } \\
\text { professional development" (P2, Appendix E). }\end{array}$ \\
\hline YouTube & $\begin{array}{l}\text { "I went to YouTube; I mean YouTube is like my go to. And I started following other } \\
\text { special ed teachers that were teaching the same grade level as me and I started } \\
\text { watching what they were doing learning from their experiences" (P5, Appendix H). }\end{array}$ \\
\hline Other & $\begin{array}{l}\text { "Teachers Pay teacher's, which is kind of like resource, networking, all just } \\
\text { combined in one spot" (P5, Appendix H). }\end{array}$ \\
\hline
\end{tabular}




\section{Chapter 4: Results}

RQ1: What do K-12 teachers perceive to be the benefits and disadvantages in using social media for professional development?

\section{1a. What value do K-12 teachers see in using social media for professional development?}

Approximately $60 \%$ of participants indicated the use of social media to explore instructional content as somewhat to extremely valuable. The highest percentage of participants found using social media extremely valuable for sharing information, finding tutorials, and exploring teaching and instructional content. Some level of value was found for all activities listed in the survey question, as shown in Figure 2. Professional development activities had a $42.3 \%$ value rating, with both neutral and little to no value responses totaling $28.85 \%$.

\section{Figure 2}

SMITPD Survey: Perceived Value of Social Media Activities

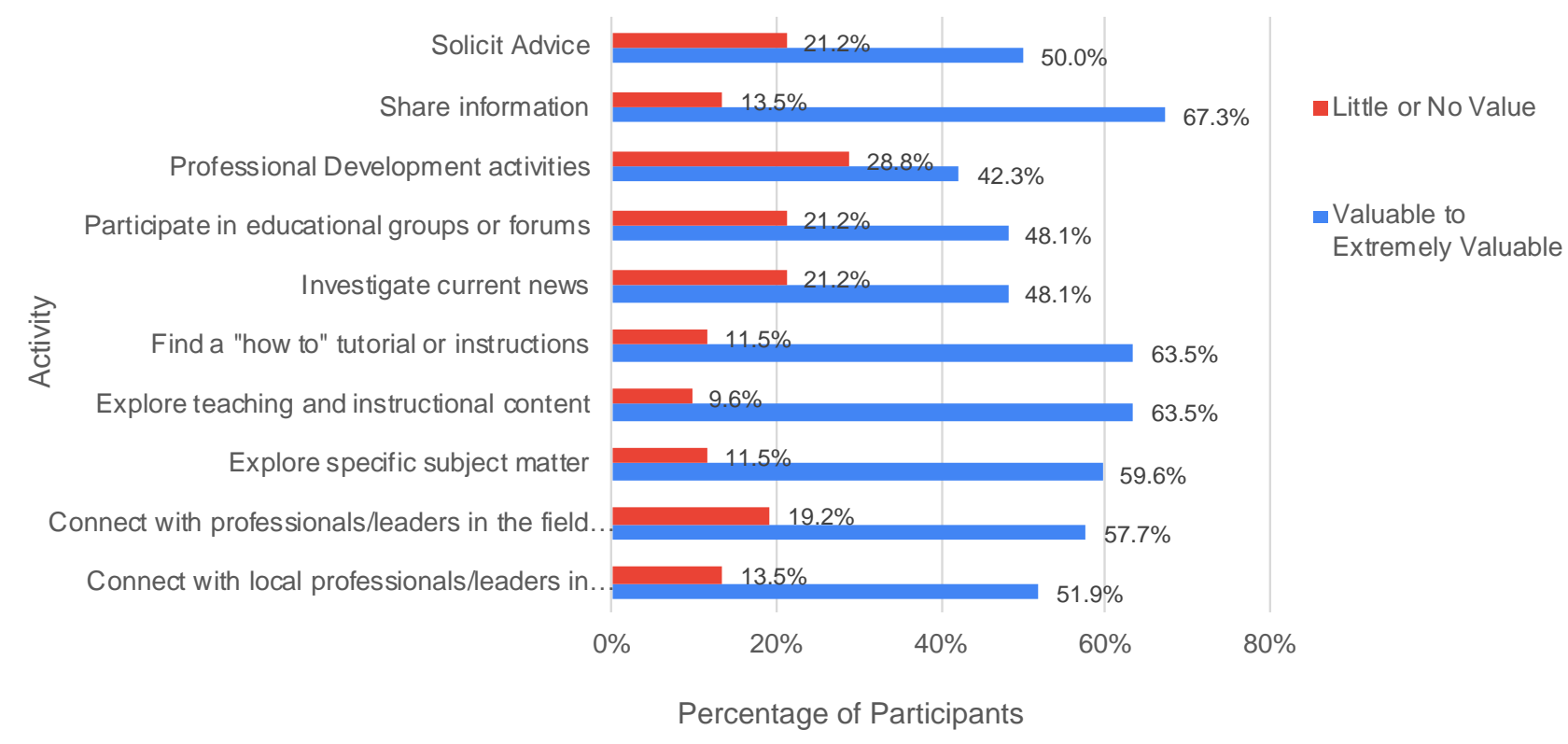

Six emergent themes surfaced during the analysis of open-ended survey and interview responses; these themes are listed in table 7. As shown in the table, recurring words and contexts 
were analyzed and used in the development of themes. Learning and Connecting had the highest perceived value among the themes. Table 7 details the activities that fall within each category. Thirty three percent of participants listed another valuable use of social media, which were originally categorized into four themes: connections, professional development, emotional support/morale, and personal. These were analyzed and merged into the six central themes.

Through interview responses, participants indicated value in the use of social media for sharing information with others, most often in the realm of online teacher communities or groups within social media platforms. In addition to sharing teaching experiences and content information, teachers also take advantage of opportunities to share with parents and communities using social media platforms. Rather than sharing alone, the opportunity for two-way communication on social media allowed teachers to connect with others in the field. Connecting with others to learn was considered valuable by all interview participants. In addition, 55\% of survey participants rated connecting as valuable to extremely valuable.

\section{Table 7}

Perceived Value of Using Social Media for Professional Development

\begin{tabular}{llc}
\hline \multicolumn{1}{c}{ Themes } & \multicolumn{1}{c}{ Specific Usage } & Mentions \\
\hline $\begin{array}{l}\text { Emotional } \\
\text { Support }\end{array}$ & $\begin{array}{l}\text { Venting frustration with current situations } \\
\text { Provide and receive encouragement } \\
\text { Share stress and frustrations to others who can relate } \\
\text { Share struggles and celebrations }\end{array}$ & 4 \\
& $\begin{array}{l}\text { Courses to renew teaching certificate } \\
\text { Formal Learning } \\
\text { W Development } \\
\text { Live talks } \\
\text { Content specific formal instruction }\end{array}$ & 6 \\
\hline Learning (Self- & $\begin{array}{l}\text { New ideas, activities, teaching strategies, technologies, skills } \\
\text { Enrichment and/or new content (exploring subject matter) }\end{array}$ & \\
Letermined) & Research and educational studies
\end{tabular}


Table 7 (continued)

\begin{tabular}{|c|c|c|}
\hline Connecting & $\begin{array}{l}\text { Learn from professional education leaders and teachers } \\
\text { Take part in digital collaboration } \\
\text { Follow other teachers executing comparable activities } \\
\text { Identify what other teachers are doing locally } \\
\text { Join groups: fellow teachers, specific content area } \\
\text { Personal: family } \\
\text { Make new professional connections } \\
\text { Get updates concerning education around the state } \\
\text { Digital Collaboration } \\
\text { Parental involvement/communication } \\
\text { Student work and feedback } \\
\text { Follow professional education organizations }\end{array}$ & 19 \\
\hline Resources & $\begin{array}{l}\text { Ready-to-use instructional resources: rubrics, plans, activities } \\
\text { Personal: recipes } \\
\text { Presentation variations } \\
\text { Professional development course creation materials }\end{array}$ & 7 \\
\hline Searching & $\begin{array}{l}\text { Solicit teaching and/or content advice and ideas } \\
\text { Find specific answers/solutions } \\
\text { Learn from others: approaches that work/don't work } \\
\text { Discover best practices }\end{array}$ & 7 \\
\hline
\end{tabular}

Both qualitative and quantitative data revealed consistent components teachers reported as valuable concerning social media for professional development. A high percentage of survey participants found specific activities valuable: connecting local and beyond, exploring subject matter and instructional content, "how-to" tutorials, current news, educational groups/forums, professional development activities, sharing information, and soliciting advice. Interview participants corroborated these values, and revealed an additional element of value as resources obtained through social media. One specific resource discussed was the online platform, Teachers Pay Teachers, which provides ready-to-use resources that save teachers time.

\section{1b: What concerns do K-12 teachers have about using social media for professional development?}

Overall, $70.94 \%$ of participants feel neutral or have no concerns about using social media for professional development. Of the concerns listed on the survey, 39.62\% percent of participants 
indicated concerns related to their school or district not allowing access to social media sites, as well as $39.62 \%$ being concerned that their teachers association or union advises against it.

\section{Figure 3}

SMITPD Survey: Level of Concerns with Using Social Media

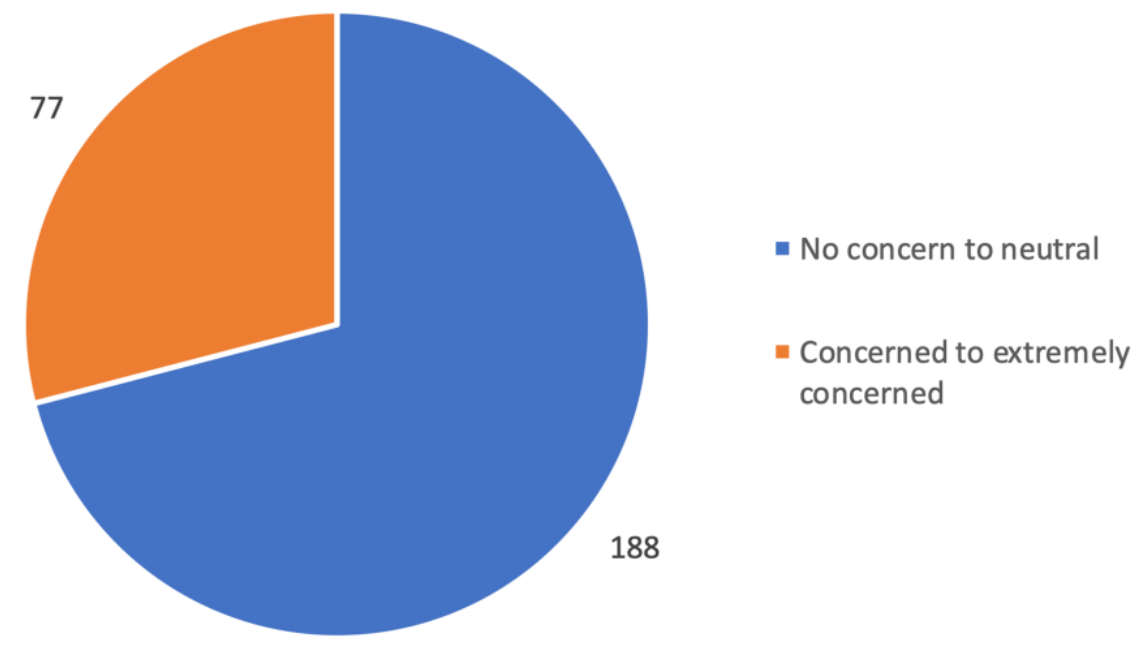

Interview participant responses aligned with the survey findings. Specifically, teachers were concerned with the "gripe sessions" and "drama" that takes place within social media groups. Participant four reported, "Facebook groups are all about other teachers or other coordinators sharing information. Sometimes it's just a gripe session." Participant five stated, "I don't use Facebook that much because sometimes I find, whatever hot button topic is happening, it becomes a forum for a lot of drama versus actual sharing some of information."

While the majority of participants, nearly $71 \%$, indicated no concerns with using social media, both datasets indicate issues with school districts not allowing the use of social media on school networks, creating a barrier to needed resources and communication methods. A recurring concern noted from the qualitative data was in regard to social media groups for teachers including complaints, hot-topic drama, and gripe sessions. While this was noted from nearly half of the 
interview participants, qualitative data denote value in social media for emotional support; many teachers reported value in the ability to "vent when frustrating situations occur", and "share with teachers who understand your stress, frustration and other feelings." So, while some teachers perceive the free expression and opinions concerning current issues as dramatic, others value this as emotional support.

\section{1c: In what ways do teachers feel self-determined professional development practices obtained} through social media impact teaching practices?

Nearly $79 \%$ of participants reported that something learned through social media impacted their teaching practice, therefore impacting student learning. Participants believe social media supports teacher professional development; only $15 \%$ disagree. More than $60 \%$ of participants feel that professional development gained through social media has a positive impact on teacher practice and student learning. According to participants, effective professional development, whether in-person or online creates growth and improvement that impacts teaching practices, thus student learning.

Higher percentages of new knowledge and learning were reported to be gained through formal professional development than through social media. Approximately $15 \%$ of participants claim that half of new knowledge, plans, ideas, etc. implemented into teaching practice is gained from social media, compared to $22 \%$ gained from formal professional development activities. 


\section{Figure 4}

SMITPD Survey: New Knowledge/Learning Gained

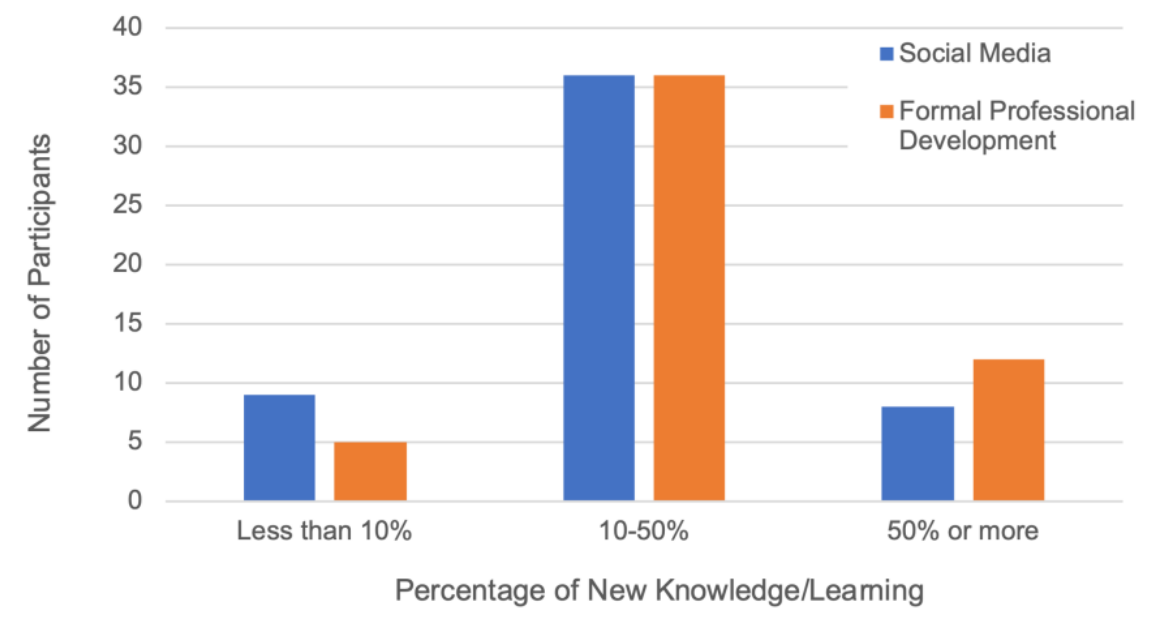

Approximately $62 \%$ of participants indicated that professional development through social media has a positive impact on both teaching practice and student learning, and $79 \%$ have learned something using social media that has impacted teaching and student learning. The interview data provided insight into specific examples of these learning experiences. In addition to new activities and teaching strategies, teachers described learning new grading practices, how to use new technology tools, and new skills, such as classroom time management. Participant one reported, "We adopted a new curriculum this year using expeditionary learning, and the resources on Facebook alone have saved my life as far as the implementation process-especially virtually". Participant two, a physical education teacher reported, "So they kind of share some different ways on how we can do a little bit of skill development, and then also grade that skill'. Participant four implemented grant-funded action research based on an article obtained from a social media site; the endeavor led to student improvement as revealed by assessment scores. Participant five, a special education teacher reported:

So, time management within a small block for a class period was really difficult for me in the beginning, and I struggled to put together a schedule that fit my specific needs in my classroom. And so that's another thing I went to YouTube for; I started going to some of 
these teacher planning channels and listening to how they set up their schedules. I learned what's called ability grouping.

\section{RQ2: In what ways do K-12 teachers use social media for self-determined professional development?}

2a: How do teachers as self-determined learners use social media for professional development?

Approximately $63 \%$ of participants reported using social media Sometimes or Often for activities that benefit professional development. One fourth of participants listed additional relevant social media uses, including: sense of community, sharing tools, connecting with students, connecting with similar interests, and research.

The highest average of participants reported using social media Often or All the Time to: Connect with professionals/leaders in the field (not local), explore specific subject matter, explore teaching and instructional content, find a "how to" tutorial or instructions, investigate current news, and participate in educational groups or forums. Connecting with local professionals was rated Sometimes by $36.5 \%$ of participants. Professional Development activities and soliciting advice were activities with the highest responses of a Never or Rarely frequency.

As shown in Figure 5, nearly $79 \%$ of participants access social media All the Time using their smart phone. One hundred percent of participants use their smart phone Sometimes, Often, or All the Time. Using a tablet or notebook Sometimes, Often, or All the Time to access social media was reported by over half of all participants; work computer is just under half, and personal computer is $71 \%$. 


\section{Figure 5}

SMITPD Survey: Frequency of Social Media Access by Device

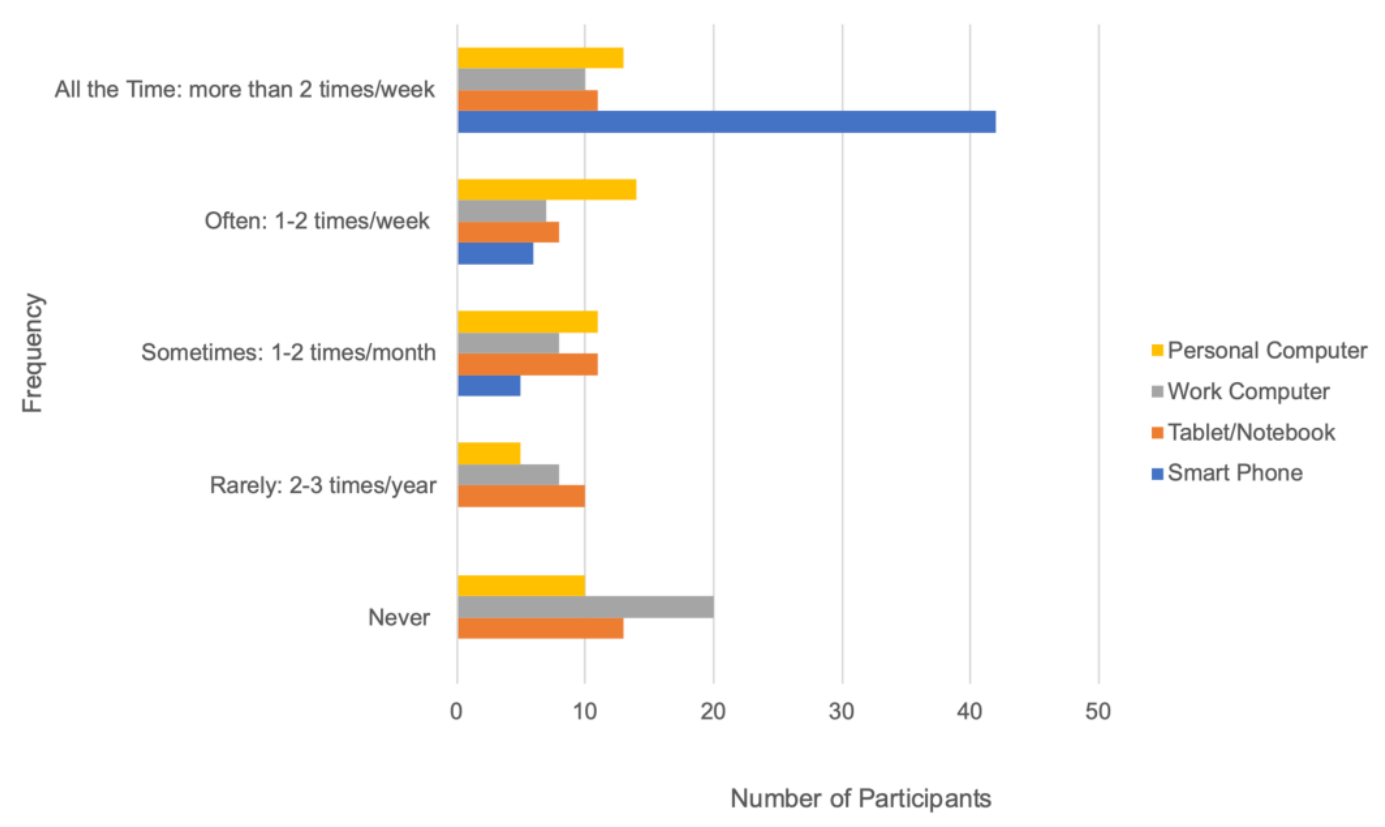

The interview failed to gather data concerning how teachers access social media, as there were no questions or discussion related to access apart from the concern of limited network access on school devices. The survey shows more than $90 \%$ of teachers access social media using their smart phone a minimum of 1-2 times per week. Personal computers are used by $51 \%$ of teachers at a minimum of 1-2 times per week, and $36 \%$ of teachers use a tablet to access social media 1-2 times per week. There are no qualitative data to provide additional support to these findings. However, both data sources confirm how teachers are using social media: to connect, learn, search, and obtain resources. In relation to searching, participant two stated, "And there are times where I just ask, I don't know how to do this. Can somebody give me a better idea of something to do?" Participant five explains a connecting experience: "So, for me, I think it was connectivity, like, connecting with other people across the United States that you don't necessarily know but you can learn from their experiences". Participant four provides an example of resources: "With Teachers 
Pay Teachers you have teachers who have been in the field for a long time and have a lot of experiences and are able to take their ideas and form a resource that is readily available and ready to use."

\section{2b. How often do teachers as self-determined learners use social media for professional development?}

The highest average of participants reported using social media Often or All the Time to: connect with professionals/leaders in the field (not local), explore specific subject matter, explore teaching and instructional content, find a "how to" tutorial or instructions, investigate current news, and participate in educational groups or forums. Connecting with local professionals was rated Sometimes by $36.5 \%$ of participants. Professional development activities and soliciting advice were activities with the highest responses of Never or Rarely frequency. Figure 6 provides a visual depiction of the frequency social media is used for specific purposes.

\section{Figure 6}

SMITPD Survey: Frequency of Social Media Use for Professional Development Activities

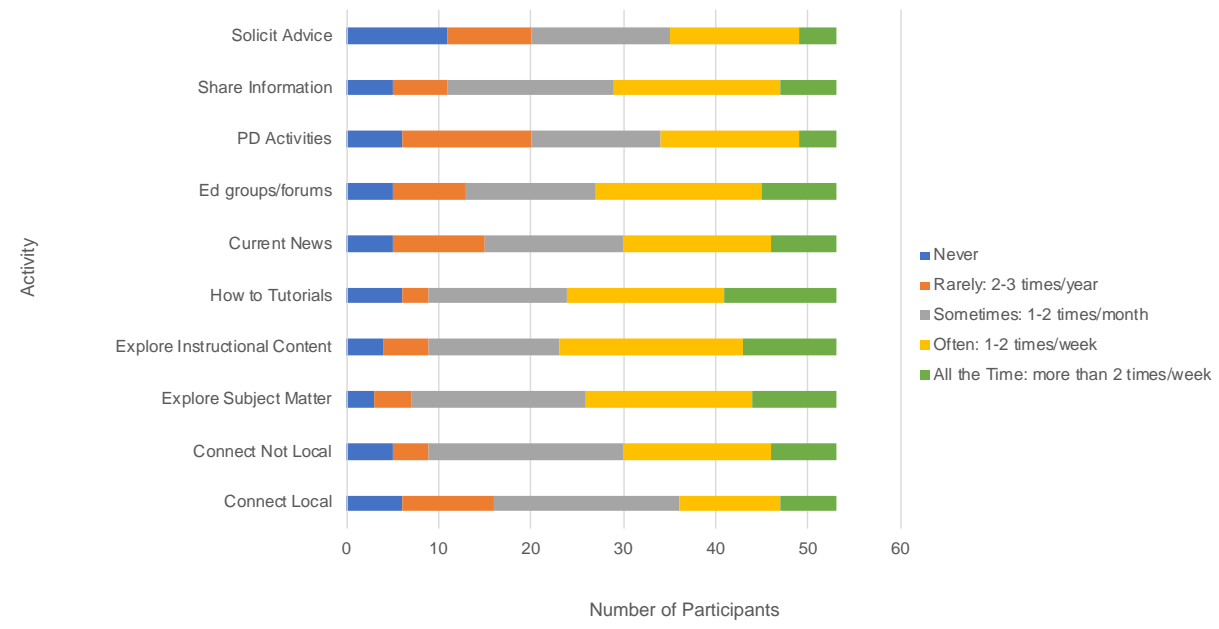

More than half of participants Never use Instagram, LinkedIn, or Twitter for professional development, as shown in Figure 7. An average of $44.6 \%$ of participants Never use the social media sites listed in survey question six for professional development. A total of $30 \%$ of 
participants use these applications Often or All the Time. Another $16 \%$ use these applications Sometimes. Facebook and YouTube are the most used applications for professional development. In addition, through the interview and qualitative survey data, teachers reported blogs, podcasts, Pinterest, Teachers Pay Teachers, and TikTok as social media applications used for selfdetermined professional development.

\section{Figure 7}

SMITPD Survey: Frequency of Social Media Platform Use

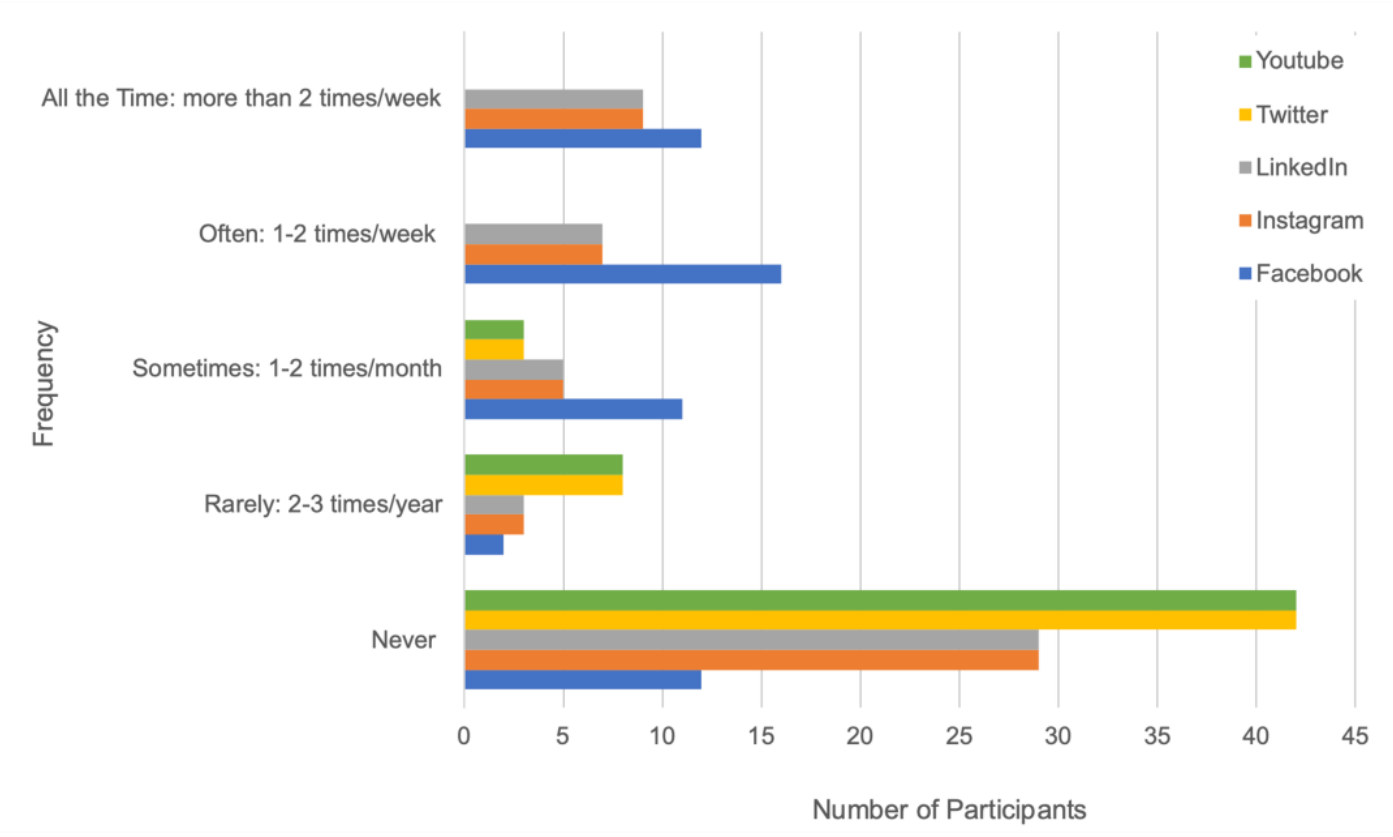

Qualitative data indicated a slightly higher use of Facebook than the survey data suggests; this was also true of Twitter and YouTube, both showing approximately $40 \%$ of participants using these often, compared to the quantitative findings of only $6 \%$. Instagram and LinkedIn were just the opposite; while the quantitative data shows $40 \%$ of participants using these often, the interviews indicated participants rarely or never use Instagram or LinkedIn.

More than $62 \%$ of participants use social media sometimes or all the time to: connect local and beyond, explore subject matter, explore instructional content, find "how-to" tutorials, 
participate in educational groups or forums, complete professional development activities, share information, solicit advice, and keep up to date on current news. All interview participants revealed also using social media for these reasons sometimes or all the time, with the exception of staying up to date on current news, which wasn't mentioned in the qualitative data.

Teachers found the greatest value in the activities that were also rated with the greatest frequency of use. As shown in figure 8, soliciting advice and connecting locally were given nearly $15 \%$ more value than the amount used at a frequency of sometimes to all the time. All other uses/activities differed only $2 \%$ to $8 \%$ in reported value and a sometimes to all the time frequency of use. This indicates that the activities used most often were considered most valuable by participants.

\section{Figure 8}

Social Media Use: Value vs. Frequency

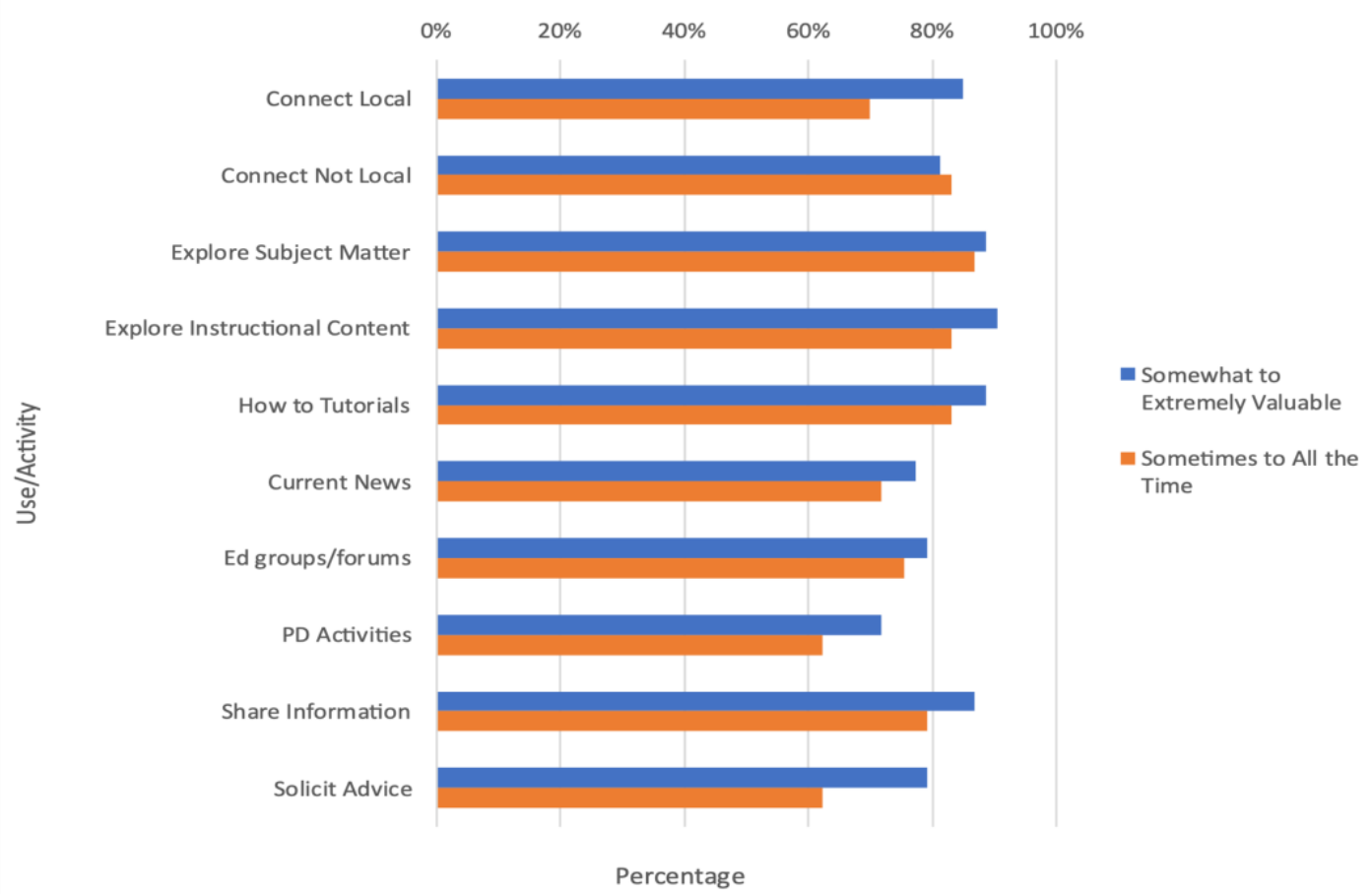




\section{2c: Why do teachers as self-determined learners use social media for professional development?}

Teachers' motivation for using professional development was reported as: to learn new teaching approaches and activities, to stay current, and to use tools that are familiar to students. Participant number three reported, “Because you don't want to be stuck back in the past, you want to keep current, because the kids nowadays, their brains are wired different." Participant four described his/her motivation for using social media for professional development:

And I feel like stuff that's posted online is usually current and what's coming up in the future, and in things to try that maybe, you know, you never know what's going to work. And I think, in teaching, especially, I think we are always looking for that next thing that's going to help our kids learn something, or some kind of new technology, or some new way to present material that's going to click with some students. To be able to use a familiar tool to the kids.

Teachers reported several motivations to use social media for professional development. In addition to the valuable uses they find, they are motivated to use social media for learning new teaching approaches and activities, staying current, and using tools that are familiar to students. One participant noted, "I want to get to know the world from the student point of view." Aside from the previously reported value participants associate with social media, additional factors of motivation were gathered from the quantitative data. These factors include learning new teaching approaches and activities, staying current, and using tools familiar to students. One participant stated, "I want to get to know the world from the student point of view."

\section{Data Triangulation}

Data triangulation involves analyzing both the survey and interview data together in order to increase the validity of a study. Triangulation allows greater confidence in the validity of the data, a deeper understanding of the research, and new perspectives on the study topic (Guion, 2013; Thurmond, 2001). These benefits are essentially the result of the diversity and quantity of data used for analysis. 


\section{Table 8}

Triangulation of Quantitative and Qualitative Data

\begin{tabular}{|c|c|c|}
\hline $\mathrm{RQ}$ & Source: Interview & Source: Survey \\
\hline \multicolumn{3}{|c|}{ Teachers' perceptions of social media for professional development } \\
\hline \multirow[t]{3}{*}{$\begin{array}{l}\text { RQ1a } \\
\text { Value }\end{array}$} & $\begin{array}{l}\text { Connect } \\
\text { Emotional Support } \\
\text { Share }\end{array}$ & $\begin{array}{l}\text { Responses greater than } 80 \text { percent: } \\
\text { Connect } \\
\text { Emotional Support } \\
\text { Share }\end{array}$ \\
\hline & $\begin{array}{l}\text { Learn } \\
\text { Explore Subject Matter } \\
\text { Explore Instructional Content } \\
\text { How to Tutorials } \\
\text { Search }\end{array}$ & $\begin{array}{l}\text { Learn } \\
\text { Explore Subject Matter } \\
\text { Explore Instructional Content } \\
\text { How to Tutorials } \\
\text { Search }\end{array}$ \\
\hline & Resources & \\
\hline \multirow[t]{2}{*}{$\begin{array}{l}\text { RQ1b } \\
\text { Concerns }\end{array}$} & $\begin{array}{l}\text { Social Media Gripe sessions, hot-topic } \\
\text { drama }\end{array}$ & $\begin{array}{l}\text { My teachers association or union advises } \\
\text { against it }(39.62 \%)\end{array}$ \\
\hline & $\begin{array}{l}\text { No access to social media on school } \\
\text { computers \& network }\end{array}$ & $\begin{array}{l}\text { My school/district does not allow me to } \\
\text { access these sites }(39.62 \%)\end{array}$ \\
\hline \multirow[t]{2}{*}{$\begin{array}{l}\text { RQ1c } \\
\text { Impact }\end{array}$} & $\begin{array}{l}\text { Growth and improvement through value } \\
\text { responses have impacted teaching } \\
\text { practice }\end{array}$ & $\begin{array}{l}\text { Professional development through social } \\
\text { media has a positive impact on both } \\
\text { teaching practice and student learning } \\
(62 \%)\end{array}$ \\
\hline & & $\begin{array}{l}\text { Have learned something using social media } \\
\text { that has impacted teaching and student } \\
\text { learning }(79 \%)\end{array}$ \\
\hline \multicolumn{3}{|c|}{ Teachers' use of social media for self-determined professional development } \\
\hline \multirow[t]{4}{*}{$\begin{array}{l}\text { RQ2a } \\
\text { How teachers } \\
\text { use social } \\
\text { media }\end{array}$} & $\begin{array}{l}\text { Connect } \\
\text { Learn, } \\
\text { Resources } \\
\text { Search }\end{array}$ & $\begin{array}{l}\text { Connect } \\
\text { Learn, } \\
\text { Resources } \\
\text { Search }\end{array}$ \\
\hline & & Smart Phone 1- 2 times/wk or more (91\%) \\
\hline & & $\begin{array}{l}\text { Personal Computer } 1-2 \text { times/wk or more } \\
(51 \%)\end{array}$ \\
\hline & & $\begin{array}{l}\text { Tablet } 1-2 \text { times/wk or more (36\%), } \\
\text { Sometimes }(21 \%)\end{array}$ \\
\hline \multirow{3}{*}{$\begin{array}{l}\text { RQ2b } \\
\text { How Often } \\
\text { teachers use } \\
\text { social media }\end{array}$} & Connect Local & $\begin{array}{l}\text { More than } 62 \% \text { use the following sometimes } \\
\text { to all the time: } \\
\text { Connect Local }\end{array}$ \\
\hline & Connect Not Local & Connect Not Local \\
\hline & Explore Subject Matter & Explore Subject Matter \\
\hline
\end{tabular}


Table 8 (continued)

\begin{tabular}{|c|c|c|}
\hline & & \\
\hline & Explore Instructional Content & Explore Instructional Content \\
\hline & How to Tutorials & How to Tutorials \\
\hline & Ed groups/forums & Ed groups/forums \\
\hline & PD Activities & PD Activities \\
\hline & Share Information & Share Information \\
\hline & Solicit Advice & Solicit Advice \\
\hline & & Current News \\
\hline & Facebook $100 \%$ & Facebook $74 \%$ \\
\hline & Twitter $40 \%$ & Twitter 6\% \\
\hline & YouTube $40 \%$ & YouTube 6\% \\
\hline & Instagram $20 \%$ & Instagram $40 \%$ \\
\hline & Linkedln $0 \%$ & Linkedln $40 \%$ \\
\hline $\begin{array}{l}\text { RQ2c } \\
\text { Why teachers }\end{array}$ & $\begin{array}{l}\text { Teachers' motivation for using } \\
\text { professional development: }\end{array}$ & $\begin{array}{l}15 \% \text { of participants gain more than } 50 \% \text { of } \\
\text { new knowledge from social media }\end{array}$ \\
\hline & $\begin{array}{l}\text { learn new teaching approaches and } \\
\text { activities }\end{array}$ & $\begin{array}{l}23 \% \text { of participants gain more than } 50 \% \text { of } \\
\text { new knowledge through formal professional } \\
\text { development }\end{array}$ \\
\hline & stay current & \\
\hline & use tools that are familiar to students & \\
\hline
\end{tabular}

\section{Summary}

The data analysis yielded important themes. Research participants found social media valuable for self-determined professional development. The analyzed data also suggested the research participants believed formal professional development activities were also as beneficial, which is, in some measure, inconsistent with the findings presented in the literature. Then again, to what degree participants found traditional professional development effective wasn't measured in this study, as the focus of this study was on the perception and utilization of social media for self-determined professional development. 
Largely, participants had no concerns that prevented them from utilizing social media for professional development. Overall, the majority of participants $(79 \%)$ reported having learned something using social media that has impacted their teaching and student learning, which aligns with the definition of effective professional development. All participants use their personal smart phone to access social media; more than $90 \%$ of participants do this more than twice per week. Considering both data sources, Facebook, YouTube, and Pinterest appear to be the most used social media networks listed in the study. Teachers Pay Teachers and educational blogs were recurring mentions throughout the qualitative data. Motivation for using social media for professional development is consistent with teachers' motivation for participating in any form of professional development; they hope to learn new activities and teaching approaches. Teachers expressed the desire to continually evolve in order to remain current/relevant, to relate better to students. 


\section{Chapter Five: Discussion}

This study was designed to examine the experiences and perceptions of teachers who use social media to engage in self-determined professional development. By reviewing the range of factors characterized as components of effective professional development, this study attempts to interpret the perceptions of teachers and provide understanding of their experiences with learning opportunities. The research questions that guided this research focused on K-12 teachers' perceptions and use of social media for professional development.

Quantitative data were collected through a survey of 53 teachers. Attitudes toward social media for professional development were analyzed using 25 total survey questions. Qualitative data were collected and analyzed through five individual teacher interviews. A list of open-ended questions was used during individual interviews (see Appendix B). Qualitative measures provided a more in-depth examination of the research questions. This section offers the qualitative findings and emergent themes, in connection with the quantitative data. The researcher purposely selected five teachers to participate in the qualitative measures. Each teacher was interviewed for 20 to 40 minutes. The qualitative findings corroborated the quantitative findings, and together supported the research questions.

The interview responses evoked more thorough responses than could be gained from the survey data. For example, the motivations for using social media were described as: "it provides a sense of community; I see that education and teachers are hurting nationwide"; " encouragement"; and "getting to know the world from the student point of view." The interview went even deeper by providing the opportunity for the participants to discuss examples of these motivations. Both passion and desperation were exemplified through the interviews. Participant five expressed: 
"Normally you look to the people in your own school that had been doing it [teaching] longer than you, to help you. Not having that was really difficult; it was kind of like blazing your own trail. There were also a lot of changes in special education at the time too. So, it was just really hard. So that [social media] definitely helped me."

Other participants also communicated times when they needed help or answers and turned to social media for solutions. Participant one declared, "We adopted a new curriculum this year using expeditionary learning, and the resources on Facebook alone have saved my life, as far as the implementation process." The desire to maintain effective and current teaching practices was expressed through the interview process with a deeper intensity than could be gathered from the survey data.

The findings, interpretations, and conclusions relating to the research questions are based on the results displayed in Chapter 4 of this study. Heutagogy or self-determined learning served as the theoretical framework of this study to guide the research and support teacher professional development. The results of this study suggest heutagogical concepts applied to social media networks are viable options for effective teacher professional development.

The theme of connecting was highly coded in this study. This aligns with more than 25 years of research and educational studies (McLaughlin \& Talbert, 2011) that substantiate the significance of teachers' interconnected relationships as a factor in school improvement. As found in this study, specific content support and mentorship is sometimes lacking in teacher learning environments; social media extends the boundaries of a physical setting, giving individuals opportunities to learn from the all over the world (Harris \& Rea, 2009).

Self-determined learning allows individuals agency with respect to how, what, and when they learn; participants conveyed this as a benefit of utilizing social media for learning. Participants 
indicated the benefit in having open access to solutions using social media groups, blogs, and tutorials. Agency, or autonomy, is also a component deemed essential for effective professional development. Autonomy reaches into the intricate, nonlinear nature of adult learning that heutagogy attempts to explain (Wehmeyer et al., 2000).

The purpose of professional development is to enhance instruction, which will increase student learning (Alberth et al., 2018). The outcomes of professional learning can positively affect student learning and achievement as well as teacher quality and efficacy (Alibakhshi \& Dehvari, 2015; Avidov-Ungar, 2016; Bayar, 2014; Chaves \& Guapacha, 2016; Yoo, 2016). When teachers are able to participate in continuous professional learning, there is greater potential for application to occur. The results of this study find teachers have a desire to regularly learn and apply new skills, strategies, and tools. The majority of participants in this study claim to have learned something using social media that has impacted teaching and student learning. Participants indicated that professional development through social media has a positive impact on both teaching practice and student learning.

\section{Implications for Professional Development Providers}

The results of this study have implications for professional development designers/providers. The literature suggests a need for more effective teacher professional learning practices. A more shared understanding of what professional development should look like in educational settings is essential. Based on the results of this study, teachers seem somewhat limited in their capacity to use social media for professional development. For example, more than half of the participants Never use Instagram, LinkedIn, or Twitter for professional development. Rather than professional development designed solely around specific subject-matter, teachers would 
greatly benefit from professional development that provides teachers with the skills and knowledge to maximize the use of social media tools for self-determined professional development.

\section{Implications for Future Research}

While a large number of participants use social media for professional development, only a small percentage reported gaining a great deal of new knowledge professional development using social media. A number of additional studies could come from this information. One study might examine from what specific sources participants are gaining the most effective professional development, and how/if these methods can be incorporated through social media. Another potential study could investigate teachers' self-determined learning practices in general for teacher professional development.

Because a few research participants mentioned following educational or teacher groups, it may merit closer examination. Information from such a study would be interesting to determine why these specific groups were attracting teachers. Also, such a study could determine if such organizations are encouraging teachers to build networks, such as personal learning networks, to engage with other group members.

Finally, many of the research participants indicated that they had already participated in or had a willingness to engage in using social media networks for professional development if recertification or continuing education credits were offered. Participants implied this would be a convenient approach for obtaining the recertification credits needed. Creating and testing a tool/instrument for authenticating social network use for recertification purposes could determine if this is a feasible and effective alternative to traditional professional development. 


\section{Final Implications}

The literature indicates a lack of effectiveness in professional development carried out through traditional methods, such as workshops and seminars. The results of this study alone confirm that teachers actively use social media for learning and professional development. With appropriate measures in place, it would be highly advantageous to legitimize this alternative professional development practice by acknowledging the value with continuing education credit. Continuing education achieved by teachers should be recognized, including that which is achieved through self-determined means. This type of professional development could be framed, or informed, by Professional Learning Networks (PLNs), where teachers reflect on their learning and experiences and share these reflections within the network (Krutka \& Carpenter, 2017). Reflection is an element of heutagogy, as well as a form of self-evaluation. While reflection at a casual level is common, reflective practice requires a conscious effort to employ 'double-loop learning', where reflection leads to re-framing ideas in order to make improvements (Blaschke, 2012; Schön, 1987). Teachers could create an annual or quarterly portfolio to detail the self-determined learning practices and outcomes, to be reviewed by the administration as a form of formal assessment.

\section{Conclusion}

Educators around the world take part in professional learning about a broad range of content through various processes. This research study lays foundational work to redefine professional development as a heutagogical process. Utilizing social media as a more effective and efficient means of professional development will benefit both teachers and students in future teaching and learning. 


\section{Limitations}

Response rates depended greatly on personal contacts as people are more likely to respond to surveys from close contacts (Saleh \& Bista, 2017). Self-selection bias of the participants might be considered a limitation of this study. Teachers participating were required to be avid users of social media, which fails to explore the perspective of the teachers who are not using social media. Steps were taken to ensure the researcher-created survey measure was reliable and valid. The use of the survey in future research would help identify issues in reliability and validity of the measure. Although the geographic locations of participants were broad, a majority of respondents came from one state. Deeper representation from several states, or countries may have helped to generalize the study results to other settings and populations. 


\section{References}

Ackoff, R. L., Emery, F. E., \& Ruben, B. D. (2005). On Purposeful Systems. Routledge.

Alberth, A., Mursalim, M., Siam, S., Suardika, I. K., \& Ino, L. (2018). Social media as a conduit for teacher professional development in the digital era: Myths, promises or realities?. Teflin Journal, 29(2), 293-306.

Albon, R 2000. Motivation, dialogue and heutagogy: Driving collaborative assessment online, proceedings of the Education and Technology Conference, IEET, Calgary, June 17-19.

Amador, P., \& Amador, J. (2014). Academic advising via Facebook: Examining student help seeking. The Internet and Higher Education, 21, 9-16. https://doi.org/10.1016/j.iheduc.2013.10.003

Anderson, T. (2005). Distance learning: Social software's killer app? Paper presented at the ODLAA 2004 Conference, Adelaide, Australia. Retrieved from http://auspace.athabascau.ca/bitstream/2149/2328/1/ distance_learning.pdf

Argyris, C. (1977). Double loop learning in organizations. Harvard business review, 55(5), 115125.

Arteaga Sánchez, R., Cortijo, V., \& Javed, U. (2014). Students’ perceptions of Facebook for academic purposes. Computers \& Education, 70, 138-149. https://doi.org/10.1016/j.compedu.2013.08.012

As Schools Lose Relevancy, Students Take ... - Project Tomorrow - SLIDELEGEND.COM. (2010, March 16). Slidelegend.Com. https://slidelegend.com/as-schools-lose-relevancystudents-take-project-tomorrow_59e05db21723dda29a3c3a80.html 
Baran, B. (2010). Facebook as a formal instructional environment. British Journal of Educational Technology, 41(6), E146-E149. https://doi.org/10.1111/j.14678535.2010.01115.x

Baratz-Snowden, J. (1993). Assessment of teachers: A view from the national board for professional teaching standards. Theory into Practice, 32(2), 82-85. https://doi.org/10.1080/00405849309543579

Barley, S. R. (1990). The Alignment of Technology and Structure through Roles and Networks. Administrative Science Quarterly, 35(1), 61. https://doi.org/10.2307/2393551

Bates, A. T., \& Sangra, A. (2011). Managing technology in higher education: Strategies for transforming teaching and learning. San Francisco, CA: Jossey-Bass.

Bayar, A. (2014). The Components of Effective Professional Development Activities in Terms of Teachers' Perspective. Online Submission, 6(2), 319-327.

Beames, S. Y. A. (2004). Towards a model of effective professional development for teachers of ICT (Doctoral dissertation, Queensland University of Technology, Brisbane).

Best, J.W., \& Kahn, J.V. (2003). Research in education.(9th ed.) Boston: Ally \& Becon. Binkley, M., Erstad, O., Herman, J., Raizen, S., Ripley, M., Miller-Ricci, M., \& Rumble, M. (2012). Defining twenty-first century skills. In Assessment and teaching of 21 st century skills (pp. 17-66). Springer, Dordrecht.

Blaschke, L. M. (2012). Heutagogy and lifelong learning: A review of heutagogical practice and self-determined learning. The International Review of Research in Open and Distributed Learning, 13(1), 56. https://doi.org/10.19173/irrodl.v13i1.1076 
Blaschke, L. M. (2014). Using social media to engage and develop the online learner in selfdetermined learning. Research in Learning Technology, 22. https://doi.org/10.3402/rlt.v22.21635

Blaschke, L.M., n.d. Strategies for implementing self-determined learning (heutagogy) within education: a comparison of three institutions (Australia, South Africa, And Israel).

Masters Thesis. Carl von Ossietzky Universität Oldenburg.

Blaschke, L. M., \& Brindley, J. (2010). Establishing a foundational framework for development of reflective thinking: Learning journals in the MDE. www. eden-online.org. [Consulta: 17 de marzo de 2014].

Blaschke, L. M., \& Hase, S. (2015). Heutagogy, technology, and lifelong learning for professional and part-time learners. In Transformative perspectives and processes in higher education, 75-94. Springer, Cham.

Blaschke, L. M., \& Hase, S. (2016). Heutagogy: A holistic framework for creating twenty-firstcentury self-determined learners. In The future of ubiquitous learning, 25-40. Springer, Berlin, Heidelberg.

Blaschke, L. M., Kenyon, C., \& Hase, S. (2014). Experiences in Self-Determined Learning. CreateSpace Independent Publishing Platform.

Bochner, S. (1965). Defining Intolerance of Ambiguity. The Psychological Record, 15(3), 393400. https://doi.org/10.1007/bf03393605

Bogdan, R. C., \& Biklen, S. K. (1998). Foundations of qualitative research in education. Qualitative research in education: An introduction to theory and methods, 1-48.

Boix Mansilla, V., \& Jackson, A. (2013). Educating for global competence: Learning redefined for an interconnected world. In Mastering global literacy, contemporary perspectives. 
New York: Solution Tree.

Borko, H., \& Putnam, R. T. (1995). Expanding a teacher's knowledge base: A cognitive psychological perspective on professional development. Professional development in education: New paradigms and practices, 35-65.

Boticki, I., Baksa, J., Seow, P., \& Looi, C.-K. (2015). Usage of a mobile social learning platform with virtual badges in a primary school. Computers \& Education, 86, 120-136. https://doi.org/10.1016/j.compedu.2015.02.015

Boyle, B., While, D., \& Boyle, T. (2004). A longitudinal study of teacher change: what makes professional development effective? The Curriculum Journal, 15(1), 45-68. https://doi.org/10.1080/1026716032000189471

Brandt, B. (2013). The learner's perspective in S. Hase, \& C. Kenyon (eds.). Self-determined learning: heutagogy in action, London: Bloomsbury, 99-116.

Bryk, A. S., Sebring, P. B., Allensworth, E., Luppescu, S., \& Easton, J. Q. (2009). Organizing schools for improvement: Lessons from Chicago. Chicago: University of Chicago Press.

Caena, F. (2017). Weaving the fabric: Teaching and teacher education ecosystem. Overcoming the fragmentation in teacher education policy and practice, 179-200.

Caena, F., \& Redecker, C. (2019). Aligning teacher competence frameworks to 21 st century challenges: The case for the European Digital Competence Framework for Educators (Digcompedu). European Journal of Education, 356-359. https://doi.org/10.1111/ejed.12345

Canning, N. (2010). Playing with heutagogy: exploring strategies to empower mature learners in higher education. Journal of Further and Higher Education, 34(1), 59-71. https://doi.org/10.1080/03098770903477102 
Canning, N., \& Callan, S. (2010). Heutagogy: spirals of reflection to empower learners in higher education. Reflective Practice, 11(1), 71-82. https://doi.org/10.1080/14623940903500069

Carpenter, J. P., \& Green, T. D. (2017). Mobile instant messaging for professional learning: Educators' perspectives on and uses of Voxer. Teaching and Teacher Education, 68, 5367. https://doi.org/10.1016/j.tate.2017.08.008

Carpenter, J. P., Kimmons, R., Short, C. R., Clements, K., \& Staples, M. E. (2019). Teacher identity and crossing the professional-personal divide on twitter. Teaching and Teacher Education, 81, 1-12. https://doi.org/10.1016/j.tate.2019.01.011

Carpenter, J. P., Morrison, S. A., Craft, M., \& Lee, M. (2020). How and why are educators using Instagram? Teaching and Teacher Education, 103149. https://doi.org/10.1016/j.tate.2020.103149

Chakrabortty, A. (2011). How British workers are losing the power to think. The Guardian, 19(12), 11.

Choi, Lee, \& Yoo. (2010). The Impact of Information Technology and Transactive Memory Systems on Knowledge Sharing, Application, and Team Performance: A Field Study. MIS Quarterly, 34(4), 855. https://doi.org/10.2307/25750708

Coleman, V. (2013). Social media as a primary source: a coming of age. Educause Review, 48(6).

Conole, G. (2012). Designing for Learning in an Open World (Explorations in the Learning Sciences, Instructional Systems and Performance Technologies (4)) (2013th ed.). Springer. 
Corcoran T. B., Shields, P. M. \& Zucker, A. A. (1998). Evaluation of NSF's Statewide Systemic Initiatives (SSI) Program: The SSIs and Professional Development for Teachers. Menlo Park, CA, SRI International.

Corcoran, T. C. (1995). Transforming professional development for teachers: A guide for state policymakers.

Creswell, J. W. (2005). Educational research: Planning, conducting, and evaluating quantitative and qualitative research. Upper Saddle River, NJ: Merrill Prentice Hall.

Darling-Hammond, L., Hyler, M. E., Gardner, M. (2017). Effective Teacher Professional Development. Palo Alto, CA: Learning Policy Institute.

Davenport, T. H., \& Beers, M. C. (1995). Managing Information about Processes. Journal of Management Information Systems, 12(1), 57-80. https://doi.org/10.1080/07421222.1995.11518070

Davies, J. (2012). Facework on Facebook as a new literacy practice. Computers \& Education, 59(1), 19-29. https://doi.org/10.1016/j.compedu.2011.11.007

Davis, B., \& Sumara, D. (1997). Cognition, Complexity, and Teacher Education. Harvard Educational Review, 67(1), 105-126. https://doi.org/10.17763/haer.67.1.160w00j113t78042

Davis, L., \& Hase, S. (2001). The river of learning in the workplace. In Proceedings of Research to Reality: Putting VET Research to Work, Australian Vocational Education and Training Research Association (AVETRA) conference. Crows Nest, NSW: AVETRA.

Deci, E. L., \& Ryan, R. M. (2000). The "What" and "Why" of Goal Pursuits: Human Needs and the Self-Determination of Behavior. Psychological Inquiry, 11(4), 227-268. https://doi.org/10.1207/s15327965pli1104_01 
Department for Education and Skills. (2001). Schools: achieving success. DfES publications.

Desimone, L. M. (2009). Improving Impact Studies of Teachers' Professional Development: Toward Better Conceptualizations and Measures. Educational Researcher, 38(3), 181199. https://doi.org/10.3102/0013189x08331140

Doherty, G., \& Graves, N. (1993). Learner Managed Learning. British Journal of Educational Studies, 41(4), 418. https://doi.org/10.2307/3121967

Doll Jr, W. E. (1989). Foundations for a post-modern curriculum. Journal of Curriculum Studies, 21(3), 243-253.

Doolittle, P. E., \& Hicks, D. (2003). Constructivism as a Theoretical Foundation for the Use of Technology in Social Studies. Theory \& Research in Social Education, 31(1), 72-104. https://doi.org/10.1080/00933104.2003.10473216

Duncan-Howell, J. (2010). Teachers making connections: online communities as a source of professional learning. British Journal of Educational Technology, 41(2), 324-340.

Emery, M. (1993). Participative design for participative democracy. Centre for Continuing Education Australian National University, Canberra.

Eraut, M. (2000). Non-formal learning and tacit knowledge in professional work. British Journal of Educational Psychology, 70(1), 113-136. https://doi.org/10.1348/000709900158001 Essentialism. (n.d.). https://www.siue.edu/\%7Eptheodo/foundations/essentialism.html.

Watson, R. (2008). Commentary on Gardner A, Hase S, Gardner G, Dunn SV \& Carryer J (2008) From competence to capability: a study of nurse practitioners in clinical practice. Journal of Clinical Nursing 17, 250-258. Journal of Clinical Nursing, 17(12), 1667. https://doi.org/10.1111/j.1365-2702.2007.02025.x

Gattegno, G., \& Australian National Training Authority. National Staff Development Committee 
(NSDC). (1996). A Guide to Facilitating Work Based Learning. Australian National Training Authority.

Gerstein, J. (2013a). Education 3.0 and the pedagogy (andragogy, heutagogy) of mobile learning. User generated education. http://usergeneratededucation.wordpress.com /2013/05/13/ education-3-0-and-the-pedagogy-andragogy-heutagogy-of-mobile-learning/

Gerstein, J. (2013b). Education 3.0: Altering round peg in round hole education. User Generated education. https://usergeneratededucation.wordpress.com/2013/06/09/education-3-0-alteringround-peg-in-round-hole-education/.

Gerstein, J. (2013c). Schools are doing Education 1.0; talking about doing Education 2.0; when they should be planning Education 3.0. User Generated Education. https://usergeneratededucation. wordpress.com/2013/03/22/schools-are-doing-education1-0-talking-about-doing-education-2-0-when-they-should-be- planning-education-3-0 /.

Gerstein, J. (2016). The Other 21st Century Skills. User Generated Education. https://usergeneratededucation.wordpress.com/2013/05/22/the-other-21st-century-skills/

Goodyear, V. A., Casey, A., \& Kirk, D. (2014). Tweet me, message me, like me: using social media to facilitate pedagogical change within an emerging community of practice. Sport, Education and Society, 19(7), 927-943. https://doi.org/10.1080/13573322.2013.858624

Gray, D. E. (2004). Doing research in the real world. London: Sage.

Greene, J. C., Caracelli, V. J., \& Graham, W. F. (1989). Toward a Conceptual Framework for Mixed-Method Evaluation Designs. Educational Evaluation and Policy Analysis, 11(3), 255-274. https://doi.org/10.3102/01623737011003255 
Greenhalgh, S. P., \& Koehler, M. J. (2017). Erratum to: 28 Days Later: Twitter Hashtags as “Just in Time" Teacher Professional Development. TechTrends, 61(3), 282-283. https://doi.org/10.1007/s11528-017-0178-0

Griffin, P., Care, E., \& McGaw, B. (2012). The changing role of education and schools. In Assessment and teaching of 21 st century skills (pp. 1-15). Springer, Dordrecht.

Guion, L. A., Diehl, D. C., \& McDonald, D. (2011). Triangulation: Establishing the validity of qualitative studies. EDIS, 2011(8), 3-3.

Guskey, T. R. (2002). Professional Development and Teacher Change. Teachers and Teaching, 8(3), 381-391. https://doi.org/10.1080/135406002100000512

Harris, A. L., \& Rea, A. (2009). Web 2.0 and virtual world technologies: A growing impact on IS education. Journal of information systems education, 20(2), 3.

Hart, J. E., \& Steinbrecher, T. (2011). OMG! Exploring and Learning from Teachers' Personal and Professional Uses of Facebook. Action in Teacher Education, 33(4), 320-328. https://doi.org/10.1080/01626620.2011.620515

Hase, S. (1998). Work-based learning for learning organizations. Capability and quality in higher education, 69-76.

Hase, S. (2009). Heutagogy and e-learning in the workplace: Some challenges and opportunities. Impact: Journal of Applied Research in Workplace E-learning, 1(1), 43-52. doi:10.5043/impact.13.

Hase, S. (2011). Learner defined curriculum: Heutagogy and action learning in vocational training. Southern Institute of Technology Journal of Applied Research, 1-10.

Hase, S. (2013a). Learner defined learning. In S. Hase \& C. Kenyon (Eds.), Self-Determined Learning: Heutagogy in Action. London: Bloomsbury Academic. 
Hase, S. (2013b). Providing A Compass: Neuroscience \& Heutagogy. Heutagogy Community of Practice. https://heutagogycop.wordpress.com/2013/03/31/providing-a-compassneuroscience-heutagogy/

Hase, S. (2014). Skills for the learner and learning leader in the 21st century. In L. M. Blaschke, C. Kenyon, \& S. Hase (Eds.), Experiences in self-determined learning (pp. 99-110). Retrieved from https://uol.de/fileadmin/user_upload/coer/Experiences-in-selfdetermined-learning.pdf

Hase, S., \& Kenyon, C. (2000). From andragogy to heutagogy. ultiBASE, 5(3). Retrieved from http://www.psy.gla.ac.uk/ steve/pr/Heutagogy.html

Hase, S. \& Kenyon, K. (2003). Heutagogy and developing capable people and capable workplaces: strategies for dealing with complexity. In Proceedings of the Changing Face of Work and Learning Conference. Edmonton, AB: University of Alberta. Retrieved Sept. 30, 2020, from www.wln.ualberta.ca/papers/pdf/17.pdf

Hase, S. \& Kenyon, C. (2007). Heutagogy: A child of complexity theory. Complicity: An International Journal of Complexity and Education, 4(1), 111-119.

Hase, S., \& Kenyon, C. (Eds.). (2013). Self-determined learning: Heutagogy in action. A\&C Black.

Hawkes, M. (1999). Exploring network-based communication in teacher professional development. Educational Technology, 39(4), 45-52.

Hiemstra, R., \& Sisco, B. (1990). Individualizing Instruction. Making Learning Personal, Empowering, and Successful. Jossey-Bass, Inc., Publishers, 350 Sansome Street, San Francisco, CA 94104. 
Hogan, J., \& Ones, D. S. (1997). Conscientiousness and integrity at work. In Handbook of personality psychology (pp. 849-870). Academic Press.

Holmes, G., \& Abington-Cooper, M. (2000). Pedagogy vs. Andragogy: A False Dichotomy? The Journal of Technology Studies, 26(2). https://doi.org/10.21061/jots.v26i2.a.8

Horn, I. S., \& Little, J. W. (2010). Attending to Problems of Practice: Routines and Resources for Professional Learning in Teachers' Workplace Interactions. American Educational Research Journal, 47(1), 181-217. https://doi.org/10.3102/0002831209345158

Hosein, J. H. (2012, October). Social technologies and knowledge sharing within and across organizations. In Proceedings of the 17th ACM international conference on Supporting group work (pp. 287-288).

Huberman, M. (1995). Professional careers and professional development: Some intersections. In Guskey, T., \& M. Huberman (Eds.), Professional development in education: New paradigms and practices (pp. 193-224). New York, NY: Teachers College Press.

Hunter, B. (2002). Learning in the virtual community depends upon changes in local communities. Building virtual communities: Learning and change in cyberspace, 96-126.

Hunter, L. J., \& Hall, C. M. (2018). A survey of K-12 teachers' utilization of social networks as a professional resource. Education and Information Technologies, 23(2), 633-658.

Hunzicker, J. (2010). Characteristics of Effective Professional Development: A Checklist. Online Submission.

Hur, J. W., \& Brush, T. A. (2009). Teacher Participation in Online Communities. Journal of Research on Technology in Education, 41(3), 279-303. https://doi.org/10.1080/15391523.2009.10782532

ISTE Standards (2017). https://www.iste.org/standards 
Jaschik, Scott, \& Lederman, Doug. (2013). 2013 Survey of faculty attitudes on technology. Inside Higher Ed. Washington D.C: Inside Higher Ed and Gallup.

Johnson, R. B., \& Onwuegbuzie, A. J. (2004). Mixed Methods Research: A Research Paradigm Whose Time Has Come. Educational Researcher, 33(7), 14-26. https://doi.org/10.3102/0013189x033007014

Jong, B.S., Lai, C.H., Hsia, Y.T., Lin, T.W., \& Liao, Y.S. (2014). An exploration of the potential educational value of Facebook. Computers in Human Behavior, 32, 201-211. https://doi.org/10.1016/j.chb.2013.12.007

Kao, C.P., \& Tsai, C.C. (2009). Teachers' attitudes toward web-based professional development, with relation to Internet self-efficacy and beliefs about web-based learning. Computers \& Education, 53(1), 66-73. https://doi.org/10.1016/j.compedu.2008.12.019

Kaplan, A. (2010). M., \& Haenlein, M. (2010). Users of the world, unite! The challenges and opportunities of social media. Business horizons, 53(1), 59-68.

Keats, D., \& Schmidt, J. P. (2007). The genesis and emergence of Education 3.0 in higher education and its potential for Africa. First Monday, 12(3), 3-5.

Kelly, N., \& Antonio, A. (2016). Teacher peer support in social network sites. Teaching and Teacher Education, 56, 138-149.

Kemmis, S., McTaggart, R., \& Nixon, R. (2013). The action research planner: Doing critical participatory action research. Springer Science \& Business Media.

Kennedy, A. (2005). Models of Continuing Professional Development: a framework for analysis. Journal of In-Service Education, 31(2), 235-250.

https://doi.org/10.1080/13674580500200277 
Kimmons, R., \& Veletsianos, G. (2014). The fragmented educator 2.0: Social networking sites, acceptable identity fragments, and the identity constellation. Computers \& Education, 72, 292-301. https://doi.org/10.1016/j.compedu.2013.12.001.

Knowles, M. S., \& Associates. (1984). Andragogy in action: Applying modern principles of adult learning. California: Jossey-Bass.

Krueger, R. A., \& Casey, M. A. (2000). Focus Groups: A Practical Guide for Applied Research (3rd ed). SAGE Publications.

Krutka, D. G., \& Carpenter, J. P. (2017). Enriching professional learning networks: A framework for identification, reflection, and intention. TechTrends, 61(3), 246-252.

Lantz-Andersson, A., Peterson, L., Hillman, T., Lundin, M., \& Bergviken Rensfeldt, A. (2017). Sharing repertoires in a teacher professional Facebook group. Learning, Culture and Social Interaction, 15, 44-55. https://doi.org/10.1016/j.lcsi.2017.07.001

Learning Theories/Print version. (n.d.). Retrieved from http://en.wikibooks.org/wiki/Learning Theories /Print_version

Lee, H., \& Liebenau, J. (2000). Temporal effects of information systems on business processes: focusing on the dimensions of temporality. Accounting, Management and Information Technologies, 10(3), 157-185. https://doi.org/10.1016/s0959-8022(00)00003-5

Liljekvist, Y. E., Randahl, A.-C., van Bommel, J., \& Olin-Scheller, C. (2020). Facebook for Professional Development: Pedagogical Content Knowledge in the Centre of Teachers' Online Communities. Scandinavian Journal of Educational Research, 1-13. https://doi.org/10.1080/00313831.2020.1754900

Lissack, M. R. (1999). Complexity: The science, its vocabulary and its relation to organizations. Emergence, 1(1), 110-26. 
Little, J. W. (1982). Norms of collegiality and experimentation: Workplace conditions of school success. American Educational Research Journal, 19(3), 325-340.

Little, J. W. (2003). Professional community and the problem of high school reform. International Journal of Educational Research, 37(8), 693-714.

Long, D.G. (1990) Learner Managed Learning. London: Kogan Page.

Louis, K. S., \& Kruse, S. (1995). Professionalism and Community: Perspectives on Reforming Urban Schools (1st ed.). Corwin.

Louis, K. S., Marks, H. M., \& Kruse, S. (1996). Teachers’ professional community in restructuring schools. American Educational Research Journal, 33(4), 757-798.

Manca, S., \& Ranieri, M. (2016). Is Facebook still a suitable technology-enhanced learning environment? An updated critical review of the literature from 2012 to 2015. Journal of Computer Assisted Learning, 32(6), 503-528. https://doi.org/10.1111/jcal.12154

McLaughlin, M. W., \& Talbert, J. E. (2001). Professional communities and the work of high school teaching. Chicago: University of Chicago Press.

McLoughlin, C., \& Lee, M. (2008). Mapping the digital terrain: New media and social software as catalysts for pedagogical change. Ascilite Melbourne, 641-652.

Meister, D. M. (2010). Experienced secondary teachers' perceptions of engagement and effectiveness: A guide for professional development. The Qualitative Report, 15(4), 880898.

Merriam, S. B. (1998). Qualitative research and case study applications in education. San Francisco: Jossey-Bass.

Merriam, S. B., Caffarella, R. S., \& Baumgartner, L. M. (2007). Learning in adulthood: A comprehensive guide (3rd ed.). San Francisco: Jossey-Bass. 
Mohsin, M. (2020b, September 28). Top 10 Facebook Statistics You Need to Know in 2020. Oberlo.Com. https://www.oberlo.com/blog/facebook-statistics.

Newman, M. (2009). Emotional capitalists: The new leaders. John Wiley \& Sons.

Orlikowski, W. J. (2007). Sociomaterial Practices: Exploring Technology at Work. Organization Studies, 28(9), 1435-1448. https://doi.org/10.1177/0170840607081138

Orlikowski, W. J., \& Scott, S. V. (2008). 10 Sociomateriality: Challenging the Separation of Technology, Work and Organization. The Academy of Management Annals, 2(1), 433474. https://doi.org/10.1080/19416520802211644

Pasek, J., more, E. I. A. N., \& Romer, D. (2009). Realizing the Social Internet? Online Social Networking Meets Offline Civic Engagement. Journal of Information Technology \& Politics, 6(3-4), 197-215. https://doi.org/10.1080/19331680902996403

Penuel, W. R., Sun, M., Frank, K. A., \& Gallagher, H. A. (2012). Using Social Network Analysis to Study How Collegial Interactions Can Augment Teacher Learning from External Professional Development. American Journal of Education, 119(1), 103-136. https://doi.org/10.1086/667756

Pervin, L. \& John, O.P. (Eds.). (1999). Handbook of personality. (2 ${ }^{\text {nd }}$ ed.). New York: Guilford Press.

Pew, S. (2007). Andragogy and Pedagogy as Foundational Theory for Student Motivation in Higher Education. InSight: A Journal of Scholarly Teaching, 2, 14-25. https://doi.org/10.46504/02200701pe

Pimmer, C., Linxen, S., \& Gröhbiel, U. (2012). Facebook as a learning tool? A case study on the appropriation of social network sites from mobile phones in developing countries. British 
Journal of Educational Technology, 43(5), 726-738. https://doi.org/10.1111/j.14678535.2012.01351.x

Pogue, L. (2009, January 7). Instructivism Vs Constructivism. Ezinearticles.Com. https://ezinearticles.com/?Instructivism-Vs-Constructivism\&id=1857834

Potkay, C. R., \& Allen, B. P. (1986). Personality: Theory, research, and applications. Thomson Brooks/Cole.

Prensky, M. (2010). Teaching digital natives: Partnering for real learning. Thousand Oaks, CA: Corwin.

Price, D. (2014). Heutagogy and social communities of practice: Will self-determined learning rewrite the script for educators? In L. Blaschke, C. Kenyon \& S. Hase, Experiences in self-determined learning ( $1^{\text {st }}$ ed.). CreateSpace Independent Publishing Platform.

Teachers Are Doing It for Themselves. (2014, May 14). Engaged Learning. http://engagedlearning.co.uk/teachers-are-doing-it-for-themselves/

Reichardt, C. S., \& Rallis, S. F. (1994). The Qualitative-Quantitative Debate: New Perspectives. New directions for program evaluation, 61, 1-98.

Reimers, F. M., \& Chung, C. K. (2016) (Eds.). Teaching and Learning for the Twenty-First Century: Educational Goals, Policies and Curricula from Six Nations. Cambridge, Mass.: Harvard Education Press.

Richardson, V. (1990). Significant and Worthwhile Change in Teaching Practice. Educational Researcher, 19(7), 10-18. https://doi.org/10.3102/0013189x019007010

Rogers, C (1951). Client centered therapy. Boston, MA: Houhton Mifflin. In Mosek, A. \& Adler, L., The self-concept of adolescent girls in non-relative versus kin foster care. International Social Work, 44(2), 149-162. 
Rogers, C. (1969). Freedom to learn: A view of what education might become. Columbus, $\mathrm{OH}$ : Charles Merill.

Rogers, C. R., \& Freiberg, H. J. (1994). Freedom to learn ( $3^{\text {rd }}$ Ed.). Columbus, OH: Merrill.

Schachter, R. (2013). Schools embrace project-based learning 2.0. District Administrator.

Schneider, B. (2008). Reform as Learning: School Reform, Organizational Culture, and Community Politics in San Diego. By Lea Hubbard, Hugh Mehan, and Mary Kay Stein. New York: Routledge, 2006. Pp. xi+304. \$36.95 (paper). American Journal of Sociology, 113(6), 1745-1747. https://doi.org/10.1086/590983

Schön, D. A. (1987). Educating the reflective practitioner: Toward a new design for teaching and learning in the professions. Jossey-Bass.

Schön, D., \& Argyris, C. (1996). Organizational learning II: Theory, method and practice. Massachusetts: Addison-Wesley Publishing Company.

Schratz, M., \& Pisanu, F. (2015). In-service teacher education: teacher quality for student success. RICERCAZIONE Six-Monthly Journal on Learning Research and Innovation in Education, 7(2), 13-18.

Schroeder, S., Curcio, R., \& Lundgren, L. (2019). Expanding the learning network: How teachers use Pinterest. Journal of research on technology in education, 51(2), 166-186.

Shulman, L. \& Sparks, D. (1992). Merging content knowledge and pedagogy: an interview with Lee Shulman. Journal of Staff Development, 13(1), 14-16.

Siemens, G. (2004). Connectivism: A learning theory for the digital age. Elearnspace.Org. http://www.elearnspace.org/Articles/connectivism.htm 
Sims, S., \& Fletcher-Wood, H. (2021). Identifying the characteristics of effective teacher professional development: a critical review. School effectiveness and school improvement, 32(1), 47-63.

Smith Risser, H. (2013). Virtual induction: A novice teacher's use of Twitter to form an informal mentoring network. Teaching and Teacher Education, 35, 25-33. https://doi.org/10.1016/j.tate.2013.05.001

Snowden, M., \& Halsall, J. P. (2016). Self-determined approach to learning: A social science perspective. Cogent Education, 3(1), 1247608.

Sparks, D., \& Hirsh, S. (2000). A national plan for improving professional development.

Stephenson, J. \& Weil, S. (1992), Quality in learning: A capability approach in higher education. London: Kogan Page.

Stephenson, J. (1994) Capability and competence: are they the same and does it matter? Capability, 1 (1), $3-4$.

Strickland, J. (2020, July 27). How Web 3.0 Will Work. HowStuffWorks. https://computer.howstuffworks.com/web-30.htm

Stuckey, B. (2004). Making the most of the good advice: Meta-analysis of guidelines for establishing an internet-mediated community of practice. Web Based Communities 2004, 183.

Sumuer, E., Esfer, S., \& Yildirim, S. (2014). Teachers' Facebook use: their use habits, intensity, self-disclosure, privacy settings, and activities on Facebook. Educational Studies, 40(5), 537-553. https://doi.org/10.1080/03055698.2014.952713 
Thelwall, M. (2009). Introduction to Webometrics: Quantitative Web Research for the Social Sciences. Synthesis Lectures on Information Concepts, Retrieval, and Services, 1(1), 1116. https://doi.org/10.2200/s00176ed1v01y200903icr004

Thurmond, V. A. (2001). The point of triangulation. Journal of nursing scholarship, 33(3), 253258.

Vavasseur, C. B., \& Kim MacGregor, S. (2008). Extending Content-Focused Professional Development through Online Communities of Practice. Journal of Research on Technology in Education, 40(4), 517-536. https://doi.org/10.1080/15391523.2008.10782519

Vygotsky, L. S. (1980). Mind in society: The development of higher psychological processes. Harvard university press.

Wagner, T. (n.d.). 7 Survival Skills of the 21st Century. 21st Century Schools. Retrieved October 3, 2020, from https://www.21stcenturyschools.com/21st-century-skills.html Wagner, T. (2014). The Global Achievement Gap: Why Our Kids Don't Have the Skills They Need for College, Careers, and Citizenship -- and What We Can Do About It (Updated, Revised ed.). Basic Books.

Wagner, T., Kegan, R., Lahey, L. L., Lemons, R. W., Garnier, J., Helsing, D., Howell, A., Rasmussen, H. T., \& Ark, T. V. (2005). Change Leadership: A Practical Guide to Transforming Our Schools (1st ed.). Jossey-Bass.

Wang, Q., \& Woo, H. L. (2007). Systematic planning for ICT integration in topic learning. Journal of Educational Technology \& Society, 10(1), 148-156.

Wankel, C. (2011). Educating Educators with Social Media (Cutting-Edge Technologies in Higher Education). Emerald Publishing Limited. 
Wehmeyer, M. L., Palmer, S. B., Agran, M., Mithaug, D. E., \& Martin, J. E. (2000). Promoting causal agency: The self-determined learning model of instruction. Exceptional Children, 66(4), 439-453.

Wenger, E. C., \& Snyder, W. M. (2000). Communities of practice: The organizational frontier. Harvard business review, 78(1), 139-146.

Wenger, E., White, N., \& Smith, J. D. (2009). Digital habitats: Stewarding technology for communities. CPsquare.

Wheeler, S. (2012). Theories for the digital age: Self regulated learning. Steve Wheeler. http://www.steve-wheeler.co.uk/2012/10/theories-for-digital-age-self-regulated.html

Yoo. (2010). Computing in Everyday Life: A Call for Research on Experiential Computing. MIS Quarterly, 34(2), 213. https://doi.org/10.2307/20721425

Zembylas, M. (2018). Professional standards for teachers and school leaders. Journal of Professional Capital and Community, 3(3), 142-156. https://doi.org/10.1108/jpcc-122017-0029 


\section{APPENDIX A \\ SMITPD Survey}

$12 / 3 / 2020$

Self-Determine Learning: Social Media's Impact on Teacher Professional Development

\section{Self-Determine Learning: Social Media's Impact on Teacher Professional Development}

The purpose of this survey is to collect feedback that will help determine: teachers' attitudes, perceptions, and practices concerning social media technologies for professional development; to what degree teachers practice self-determined learning for professional development using social media technologies; and what characteristics of Learning Leaders are present within teachers' social technology practices used for professional development.

The following questions were derived from well-validated portions of several attitudinal surveys that have been used with teachers in the past. Your responses will help develop a profile of how teachers view and use social media technologies. Please complete all items even if you feel that some are redundant. Your answers will remain confidential.

It may take 5-10 minutes to complete this survey. Once you submit the completed survey, you will be automatically registered to win a \$50 Target gift card, or one (1) of three (3) \$15 Starbucks gift cards. Thank you for your time!

Leah McJilton

West Virginia University

* Required

1. Email address *

Participation Question A

2. Are you a current teacher/instructor? *

Mark only one oval.

Yes

No

Participation Question B 
3. Do you currently use one or more social technology tools or social media sites? * Mark only one oval.

Yes

No

Basic

This section of the survey collects basic information in order to build a demographic Information framework for analysis.

4. What is your gender?*

Mark only one oval.

Female

Male

Prefer not to say

5. What is your age (in years)? *

6. What is the content area/subject you currently teach? *

7. What grade level do you teach? *

8. For how many years have you been teaching? * 
$\operatorname{lxxxi}$

$12 / 3 / 2020$ Self-Determine Learning: Social Media's Impact on Teacher Professional Development

9. Please indicate your education level. *

Mark only one oval.

Bachelor's Degree

Some Graduate Credits

Master's Degree

Doctoral Degree

Other: 
lxxxii

$12 / 3 / 2020$

Self-Determine Learning: Social Media's Impact on Teacher Professional Development

10. In what state do you teach? *

Mark only one oval.

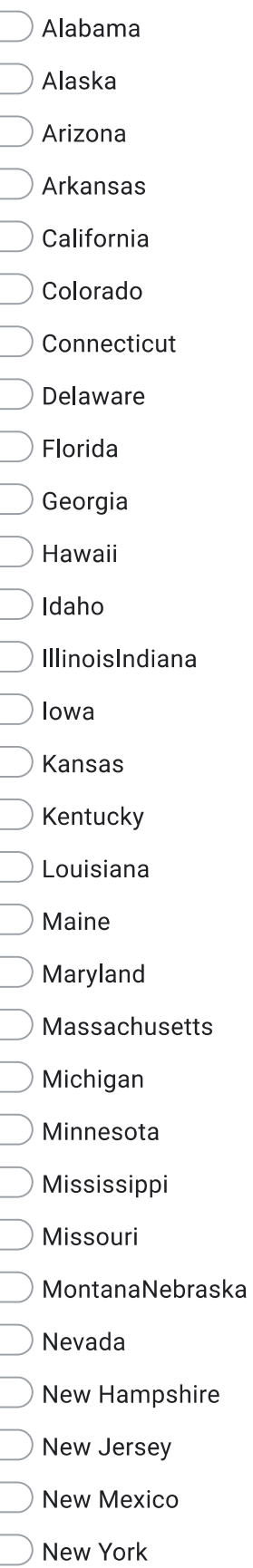

https://docs.google.com/forms/d/1aum8md8DJ90LQaZ156sW7yed7v9L6GDmGf97-TmLgu8/edit 
lxxxiii

$12 / 3 / 2020$

Self-Determine Learning: Social Media's Impact on Teacher Professional Development

North Carolina

North Dakota

Ohio

Oklahoma

Oregon

PennsylvaniaRhode Island

South Carolina

South Dakota

Tennessee

Texas

Utah

Vermont

Virginia

Washington

West Virginia

Wisconsin

Wyoming

11. In what county do you teach?*

Social Media for Professional Development

The following questions are being used to gain insight into the ways and reasons teachers use social media for professional development. 
12. Whether or not you actively participate in the following, please indicate the value you see in using social media for the following purposes: *

$1=$ No Value $5=$ Extremely Valuable

Mark only one oval per row.

\begin{tabular}{|c|c|c|c|}
\hline $\begin{array}{l}1 \text { - No } \\
\text { Value }\end{array}$ & 2 & 3 & 4 \\
\hline
\end{tabular}

Connect with local

professionals/leaders in the field

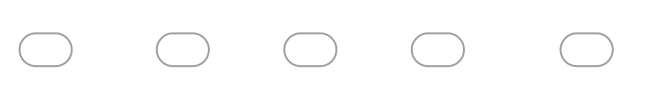

Connect with

professionals/leaders in the field (not local)

Explore specific subject matter
Explore teaching and instructional
content
Find a "how to" tutorial or
instructions
Investigate current news
Participate in educational groups
or forums
activities
Share information
Solicit Advice


13. If you selected "Other" in the previous question, please describe. Otherwise, proceed to the next question.

14. Please rate your level of agreement with the following statements. *

$1=$ No Value $5=$ Extremely Valuable

Mark only one oval per row.

\begin{tabular}{|c|c|c|c|c|c|}
\hline & $\begin{array}{l}1 \text { - Strongly } \\
\text { Disagree }\end{array}$ & $\begin{array}{c}2 \text { - } \\
\text { Disagree }\end{array}$ & $\begin{array}{c}3- \\
\text { Neutral }\end{array}$ & $\begin{array}{c}4- \\
\text { Agree }\end{array}$ & $\begin{array}{l}5 \text { - } \\
\text { Strongly } \\
\text { Agree }\end{array}$ \\
\hline $\begin{array}{l}\text { Social media supports teacher } \\
\text { professional development. }\end{array}$ & & & & & \\
\hline $\begin{array}{l}\text { Professional Development } \\
\text { teachers experience using } \\
\text { social media has a positive } \\
\text { impact on teaching practice. }\end{array}$ & & & & & \\
\hline $\begin{array}{l}\text { Professional Development } \\
\text { teachers experience using } \\
\text { social media has a positive } \\
\text { impact on student learning. }\end{array}$ & & & & & \\
\hline
\end{tabular}


15. Rate your level of concern with the following issues of using social media sites. *

$1=$ No Value $5=$ Extremely Valuable

Mark only one oval per row.

I am already too busy and don't
have time
I already have too many online
communications
My school/district does not allow
me to access these sites
I do not see the value for me
professionally
My teachers' association or union
advises against it
Concerned

16. Has something you learned through social media impacted your teaching practice?

Mark only one oval.

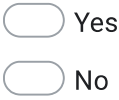

17. Has something you learned through social media and implemented in the classroom impacted student learning? *

Mark only one oval.
Yes
No 
18. How often do you use social media sites for the following reasons: *

Scale definitions: Never $=$ never used it before Rarely $=$ a few times/YEAR Sometimes $=1-2$ times $/$ MONTH Often $=1-2$ times $/$ WEEK All the time $=$ MORE than 2 times $/$ WEEK

Mark only one oval per row.

Connect with local
professionals/leaders in the field
Connect with professionals/leaders
in the field (not local)
Explore specific subject matter
Explore teaching and instructional
content
instructions
Investigate current news
Participate in educational groups or
Porums
Professional Development activities


19. Please list any other reasons you use social media technologies, sites, or apps in addition to those listed above.

20. Select how often you use the following social media applications for selfdetermined professional development. *

Scale definitions: Never $=$ never used it before Rarely $=$ a few times/YEAR Sometimes $=1-2$ times $/$ MONTH Often $=1-2$ times $/$ WEEK All the time $=$ MORE than 2 times $/$ WEEK

Mark only one oval per row.

Facebook Rever Rarely Sometimes Often All The Time

21. Please list any other social media applications you use for self-determined professional development. 
22. Access to social media - This question is designed to understand how you access social media and to understand any barriers you have to access. *

Scale definitions: Never $=$ never used it before Rarely $=a$ few times $/$ YEAR Sometimes $=1-2$ times/MONTH Often $=1-2$ times $/$ WEEK All the time $=$ MORE than 2 times $/$ WEEK

Mark only one oval per row.

smart phone

23. What percentage of new knowledge, plans, ideas, etc. implemented into your teaching practice is gained from formal professional development activities? * Formal professional development consists of organized activities, e.g. courses, seminars, workshops, conferences, etc.

\section{Mark only one oval.}

Less than $10 \%$

$10-25 \%$

$25-50 \%$

$50-75 \%$

More than $75 \%$ 
24. What percentage of new knowledge, plans, ideas, etc. implemented into your teaching practice is gained from self-determined professional development using social media?*

Formal professional development consists of organized activities, e.g. courses, seminars, workshops, conferences, etc.

Mark only one oval.

Less than $10 \%$

$10-25 \%$

$25-50 \%$

$50-75 \%$

More than $75 \%$

25. Would you be willing to participate in a brief virtual interview concerning the subject matter of this survey, in order to provide additional data for the study. * Mark only one oval.

Yes

No

This content is neither created nor endorsed by Google. 


\section{APPENDIX B \\ Interview Guide}

\section{Social Media Impact on Teacher Professional Development (SMITPD) Interview Guide}

\section{PARTICIPANT:}

DATE:

1. Describe some of the best things you learned or experienced as a teacher using social media.

2. Give an example of something you learned or experienced on social media that resulted in a change or improvement to your teaching practices and the impact on students.

3. Describe how you use social media to obtain professional development in the top 3 (or 4 or 5) areas of frequency (based on the frequency indicated in survey question 8).

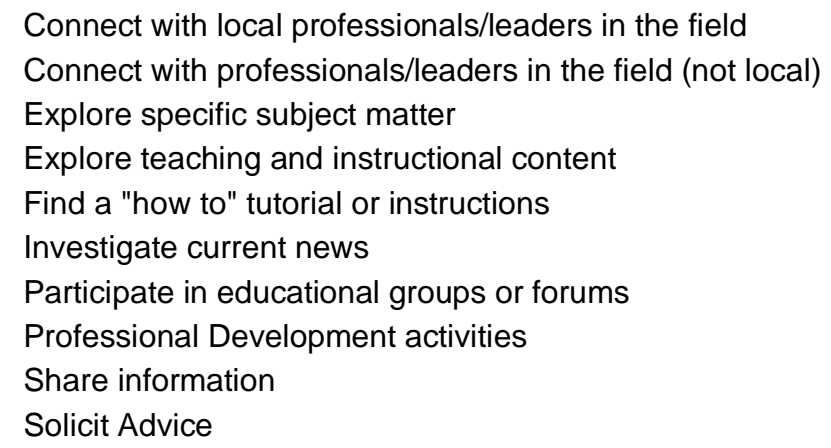

4. What motivated you to use social media for learning/professional development? 


\title{
APPENDIX C
}

\section{Cover Letter}

\section{West VirginiaUniversity. Cover Letter OFFICE OF HUMAN RESEARCH PROTECTION}

\author{
Dear Participant,
}

This letter is a request for you to take part in a research project that will help determine: teachers' attitudes, perceptions, and practices concerning social media technologies for professional development. This project is being conducted by Leah McJilton in the Instructional Design \& Techology department at WVU under the supervision of Dr. Ugur Kale, associate professor at WVU, in the Instructional Design \& Technology department, to fulfil requirements for a Doctorate degree in Instructional Design \& Technology.

If you decide to participate, you will be asked to complete the online survey. Your participation in this project will take approximately 5-10 minutes. You must be a current teacher, and use some form of social media to participate. You will be entered in a drawing to win a \$50 Target gift card, or one (1) of three (3) \$15 Starbucks gift cards for participation.

Your involvement in this project will be kept as confidential as legally possible. All data will be reported in the aggregate. You will not be asked any questions that could lead back to your identity as a participant. Your participation is completely voluntary. You may skip any question, and discontinue the survey at any time. West Virginia University's Institutional Review Board acknowledgement of this project is on file. Your email address will be requested so that we can enter your name in the drawing for the gift cards. However, it will be stored separately from any data collected in the study.

If you have any questions about this research project, please feel free to contact me at 304-669-1438 or by e-mail at leah.mcjilton@gmail.com or the supervising faculty member at ugur.kale@mail.wvu.edu. If you have any questions about your rights as a research participant, please contact the WVU Office of Human Research Protection by phone at 304-293-7073 or by email at IRB @ mail.wvu.edu

I hope that you will participate in this research project, as it could help us better understand teachers' attitudes, perceptions, and practices concerning social media technologies for professional development. Thank you for your time and consideration.

Sincerely,

Leah McJilton

Chestnut Ridge Research Building

886 Chestnut Ridge Road

Phone: 304-293-7073

Fax: 304-293-3098

http://oric.research.wvu.edu
PO Box 6845

Morgantown, WV 26506-6845
P a g e | 1

V2019.06.03 


\section{APPENDIX D}

\section{Participant 1 Interview Transcripts}

We adopted a new curriculum this year using expeditionary learning, and the resources on Facebook alone have saved my life as far as the implementation process - especially virtually. A lot of people have mimicked the lessons and created their own google slides that go right along with the lesson, so we've been able to use those. Facebook is really the only social media I use for education purposes.

And so, yeah, the actual curriculum company created some slides on their own. But we after we pulled our benchmark assessment data, we realized that the questioning that was on the slides from the actual curriculum company did not align with our benchmark test. And so, the kids were having a hard time with especially the vocabulary portion of it. So, here's an example: the new curriculum uses the word gist a lot. And so, gist as kind of like summary or main idea or whatever.

The Open up Resources on Facebook created new Detroit slides that still align with the curriculum. But were more susceptible for the kids were easier for the kids to follow along with as far as the questioning and that along with our benchmark data

And then probably just solicit advice. So, the top three would definitely be connect with professional leaders in the field, not local. I know that I usually use it to connect with people who are not local, but still teaching the same curriculum that we are, because it's like the curriculum that we've adopted is not that popular yet. But I do feel like the results that people have gotten from it, it's going to become more popular. So that's what I really used it for, is to connect with people who have already implemented that curriculum and just pick their brains about the intricacies of it, like how do we do skills block and how do we pull small groups and what about the assessments and things like that.

Yeah. So, because we weren't, like, versed in the in the actual curriculum that it was it's funny because the owners of the curriculum were the ones who encouraged us to reach out to this group on Facebook because they knew it existed. And so, they would say to us like, hey, if you can't find the answer, go to open up resources and somebody will be there that will be able to answer for you. OK, so that's how we use it. But and I'm sure that it's on Instagram and maybe who knows what else, but. I don't use it in those platforms. Professional development activities, so because I'm responsible for creating the professional development, a lot of times I'll whatever my principal gives me the topic or whatever she says like example, this Friday, I have to do one on clear learning targets and how to make them more interactive, virtually especially for younger kids. It's like an action statement. And so, I've reached out on social media and said, hey, somebody give me some ideas on how I could create a PDE around this.

Yeah, I mean, I do, but not really for educational purposes, like I feel like I have to just be really careful even what I'm looking for, because especially with us being virtual now, like, I can't post anything on Facebook during school time. And then I look at stuff on open up resources on my Facebook page, on my professional laptop, and I'm like, oh my gosh, I hope they can't see that I'm on Facebook, but I'm really legit looking at the open up resource page. 


\section{APPENDIX E}

\section{Participant 2 Interview Transcripts}

Yeah, I think Twitter, I've really got a broad a lot of good ideas, too, you know, different content, things that we can see different ways how we can teach. And even as a, I got my administrative degree, and just looking forward, you know, kind of toward that area, there's a lot of good stuff on there that people are sharing, you know, as far as like ideas, they work with teachers, or staff or culture. So, there's a lot of great stuff on there.

Going back to Twitter, they a lot of grading practices that people share, you know, how we grade things, because we are a lot of participation-based things. And, you know, we have to hold them accountable as far as teaching guilt. So, they kind of share some different ways on how we can do a little bit of skill development, and then also grade that skill. So, they have different rubrics that, you know, people chaired in different ways to teach in in different ways to grade.

On the share information, we use Facebook more for that, I think, than I do on Twitter. Because I think more parents are on Facebook, or this Twitter's more student oriented, but we like to leave to do on FTC them but sad. And I would do these AI, nightly wellness type thing where we try to teach a content, or whatever our unit would be, we try to make a little one-minute video. And then we would share that so that you know, people could see what we're doing. community members can see what we're doing. And then students can actually learn a little bit about it.

So, kind of use Facebook for explore teaching instructional content and share the information. Now just kind of sometimes, parent might watch and be like, hey, here you go. What would you teach you to join? Yeah, obviously, we're not gonna be friends with our students on that point. So, it's really just a parent, kind of watching the videos. Yeah, I mean, we kind of did that with, with trying to do this less screen time initiative, what we're doing. We're picking people who have perfect attendance in our virtual classroom or remote learning classes. And then we're going out to their house and then giving them a piece of equipment. And then we could take a picture with him. Then we put it back on social media to let the you know, community and parents know that. You know, there are kids actually trying there's kids that actually are popular. Depending but, you know, we kind of want to reward them too.

I think the biggest part what I took a professional development class to renew my teaching certificate, and it was on PLN, the personal learning network. And she was real big on Twitter, and I was on it, just to have it, I really wasn't using it for that purpose. And we had to do all this other, you know, kind of research and get ideas. And that's when I kind of discovered a whole new world. Yeah, with educators on that platform, like a Facebook night, and I tried to look at different things, but I think Twitter and Pinterest are probably two of the bigger one for teaching and professional development.

I mean, I'll look up board scores and stuff, but and I occasionally a post on them. But a lot of it just I'm just kind of going down through there and seeing different people's ideas. And, determine if it's something I can use or not. 


\section{APPENDIX F}

\section{Participant 3 Interview Transcripts}

I've learned a lot of different strategies to use with the kids, different platforms.

Using different types of technology. Because without seeing it on social media, I would have never heard of it never tried different things. Okay, like for the local professional leaders in the field.

I can get some homes to other buildings, or within like the county or other counties. So, I can get through social media, see what people put on Instagram, or Facebook. And that can give me some ideas of things I can use in my classroom, maybe a project someone's done or something like that. Not local, you get to see the experts all over actually all over the world. Because I'm on all kinds of blogs, and they're International. So, you can see different things to different people are doing, it's just not one way, just the way we know here. Because there's just a lot of different ways to do things. Specific subject matter. I'm on a lot of blogs for math, and it will give you a lot of different types of hands-on activities that maybe I haven't thought of. Same thing with the teaching instructional content, it's sort of the same.

Because or it may be things that you maybe I used in the past, but I didn't use it. Don't use now, because I've forgotten about them. Because with each set of kids, you have to use different strategies, right? So sometimes that just refreshes your memory or somebody has something new or just a new twist on something, just one little tweak. And it can make all the difference in the world of how you teach things. The how to use that a lot last year and a half. Really how I've learned how to use all this technology, because we did not have much professional development, we were just told to get on and either google it or do the State Department. Sometimes the State Department stuff was really good. But a lot of times it was just easier. Like there's a Teams groups on mn. And now you can just put a question out there and somehow give you a tutorial teaches one step at a time something to do, which is real easy to do. And that's the same thing. Like with the current stuff, that's just way keeping current. I'm on gobs of Instagram and Facebook groups for first grade, and like math and reading. So, it gives you lots of different ideas, different perspectives.

In professional development, I do lots of webinars off of social media. What else I've done book studies. I think what else I've done a lot of times, I'll just do live talks. I know there's one that I use with boom cards and that lady just once a month. It's a group of first grade teachers, there's 20 of us and we get on once a month and just discuss what skills and things we're doing and then this lady makes the boom cards for us and sends it to us are those other teachers that you know are just in that group on? Oh, there are just 20 teachers in the group and they're from all over the United States. I'm in there good to share information with other people, because you might have something that's helped somebody else or something they say might spark something that I'm doing in class like, Oh, I can do that a different way with a different twist. Mm hmm. And there are times where I just ask, I don't know how to do this. Can somebody give me a better idea of something to do?

Okay, this is a lot easier than it was years ago, because years ago, you didn't have that writing. To you just came up with it yourself. You talk to just the people in your building. Now. Now you have the whole world at your hands. And you can almost always find some kind of answers somebody's idea. And you can try and if it doesn't work for you, that's fine, too.

And that you can't throw all the old out. Because a lot of that still works. And some things new are better. But some of the old things are good, too. And you may have to just put a new twist on it with technology. Because you don't want to be stuck back in the past, you want to keep current to keep, because the kids nowadays, their brains are wired different. They're not used to sitting and listening. It's got to be fast paced. 
And a lot of that has to do with the technology. The only problem is we don't always have the technology to use with what you want to do. Yeah, that's part of the issue. 


\section{APPENDIX G}

\section{Participant 4 Interview Transcripts}

I actually did my own action research and got funded for a grant to do something that I saw on social media. So, Wow. Yeah. So that's what I thought we were talking about. And, but I just wanted to make sure that is a great example, because that's how it kind of works for me too, but not very many people have mentioned that. And I know it's hard like trying to just think of stuff like during a survey or you know, something you're just trying to think and write, I can't remember what I did yesterday, let alone, you know, looking back through a couple of years of teaching, like what I actually used from social media, right? I'm the same as you like, I'll see something on there. And then I go further with it myself.

Well, my one and two kind of go together so you can put it wherever you want.

But I will tell you that I was on Facebook saw a post from that Edutopia, something like that. And, and it was talking about project-based learning, which I'm a big fan of, but it was, I think, a fifth-grade classroom. And I thought, well, I want to just watch this or look at this, read this article, just to see if I could apply it to high school and so then what I did was I watched these videos, and it was about taking multiple classes, like if you--their example was it was a fifth-grade classroom, and they had four or five teachers that taught a fifth-grade classroom, and it was a lesson and they all gave a test. And they scored it and they came together as a collaborative group of all fifth-grade teachers on this matter. And what they did was they took the kids that scored the highest in all five classes and put them in a group took the kids that scored the lowest in another group and then the kids that were in the middle of the road, they divided those in multiple groups and then the teacher had the highest average or the most kids that were in that top group, they know that that teacher must have provided something extra or a way of presenting the material that just clicked with those kids to score that high. So, they took that teacher and put them with the lowest group, once they group them so that she could reteach.

So, then you form these groups that the higher group was an accelerated group. So, you took that same concept, but you extended it, and you put a teacher that wasn't the highest, you know, the teacher that had the highest scores, but another teacher that would take and move for that extension, to push them further. And then you took the teacher that had the highest average, you put them with the lowest group for the reteach. And then the middle of the road, you just split those up with the other teachers and you did another lesson with them. So, it was it was it was the same test. And then they divided those kids up. And so, then the reteach, that teacher would go back over the material, again, you have a post test, then to see and the results were phenomenal how that push scores up. And so, I wrote a grant. And we did that. And we developed the test and did the different lessons, it was in conjunction with something else that I had been doing with the State Department. And with a design collaborative group. And we two other teachers in my building, we did this in algebra, one for ninth grade. And it was really neat to see the kids respond, because here, you know, you're used to a high school teacher, you have this teacher all, all year long for this subject. And what when we did this, it was like every unit that we did, we had this experience. And so, they would get that pretest or they would I say it's a pretest. But it really wasn't it was a test after, you know, the material had been presented or the unit had been presented. They took a test, then we evaluated them and put them in different groups. And then two other teachers came in with me, and we and we sorted these kids out. And then whatever teacher had the highest number of high scoring students took the lowest group. And so, it was fun, because I could tell my kids, okay, you, you, you, you are all going to go to this other teacher's room, and I got kids that I hadn't had the experience of working with. And the other two teachers got kids. Did I have any of my own kids stay with me? Yes, I did. But then we all would teach another lesson, or we would reteach material, and then they would test again. And our scores went way up. Really? For those 
concepts. Yes. So, it's really, it was a neat opportunity. But had I not been on social media to see this, I would have, you know, never tried that or received grant money to further that study for it. So, I got to write all that up and do that is really in trouble.

I highlighted the ones that you marked as the highest frequency user. Yeah, probably the professional development one is probably also in Well, honestly sharing information, because all those advanced placement classes as AP classes, those Facebook groups are all about in other teachers or other coordinators sharing information. And what they did that worked or what they did that didn't work, or most of the time, it's a big discussion about they're irritated with the fact that that their AP classroom that they use with their students isn't opening or isn't being able to access some of the extensions that they have on there. So sometimes it's a gripe session or a share session where you can get activities and different things from other teachers that have that are right, they're doing the same thing.

So, the only other thing, social media wise is for resources, especially with doing this remote learning right now. I usually will take guided notes, or whatever. And I will teach on teams and record because we have to use Microsoft Teams. That's what the platform that the county wants us to use.

I will take that information. And I will record myself and then put it up on Google Classroom for them. But I also utilize a review page on my google classroom, that I will search YouTube videos. So, I look for other teachers that are presenting the same material, and might have a different way or a different take on the presentation style than what I normally do. So, kids get multiple Yeah, I guess ways to view the material. Sometimes it's like cartoons, some of sometimes they I find a song or something to have them listen to that will help them remember a formula. But YouTube is also used as a review page. So ,before a test, they might have all copy links to YouTube for them to review topics that will be on the test.

So that they can see a different way of a presentation model. So those are really the main things that I use, and again, for advanced placement classes, all those.

I just coordinate all those groups while I'm in a coordinator, Facebook group, but all I know all my AP teachers here also are in their content Facebook group for their AP course that they teach, and they utilize that a lot.

For English Lit, or stats, or calc, or whatever that we offer here, each of those areas have their own Facebook group that they belong to, to those teachers. And then I'm I belong to the coordinator group. So that has been used a lot, but I just wanted to make sure I understood what you were talking about, because

I do have some specific examples, but it was, like things that I saw on Facebook or media that then I researched further, but I, you know, saw that post because I belong to that group.

So, and I'm just getting ready to do. And I don't know where this came from. So, I don't know if it was social media or not. But I'm getting ready to utilize another, I don't even know the name of it. That's awful. It's in my email. But I came across another.

It's a professional development opportunity, because I actually wrote it up for professional development for the math department. So today, after school, I'm presenting it to them, but it's all on math modeling. And I am going to send them three short videos to watch this math modeling.

I guess it's kind of its, I guess it be professional development for them. But it will eventually lead to an online competition that we could participate in. It's at like a nationwide platform. So, they're going to get those videos and watch it and they're going to get credit for professional development for after school working with me on math modeling. So that's the second thing that we're using.

But I, I received this from my administrator that thought maybe it'd be something that we could utilize with the math department. So that's, I'm just gonna roll with that today for professional development for them. But we have, well, I just know, our math department works really close together, we are lucky enough that 
well, both our administrator and our one of our assistant principals, they were both former math teachers night. So, I think that makes a difference when we say, hey, look,

we actually have three teachers that are an algebra team, although we teach other things, it's the core algebra teachers, and we get a common planning. So that we can work together and collaborate together. Same thing happens with the three teachers that also teach geometry, they get that common plan, because we try to model our classrooms with the same content and the same presentation of material and the same tests and the same projects so that we don't have kids that want to jump from this teacher to this teacher, because they don't have to do as much work. We try to really keep it even keeled so that we don't have that problem. So as far as question four, what motivates to me, a teacher always is going to continue to learn. And I feel like stuff that's posted online is usually current and what's coming up in the future, and in things to try that maybe, you know, you never know what's going to work just like I didn't know that one.

That one video or that one article I read from Edutopia was going to motivate, to see, well, what if you know, who wants to just start trying to do their own action research in their classroom? But to me, we always want to continue to learn. And I think, in teaching, especially, I think we are always looking for that next thing that's going to help our kids learn something, or some kind of new technology, or some new way to present material that's going to click with some students. And quite honestly, our students are in all the online social media. That's what they're used to they, that's their thing. We're the ones that are having to learn it. Well. My age is having to learn it more. To be able to use a familiar tool to the kids.

I had to share my Facebook because I can't pull Facebook up on my computer when I'm at school. So I had to copy that link and send to my email so I could get

Alright. I have to turn Wi Fi off on my phone. Because the state server blocks it. What am I called that? So, on a computer, I don't know how you would get on unless you are running off a hotspot on your phone, you wouldn't be able to get in. And the documents that we have to sign for Marion County says that we will not or you know, that's violating our access or our user agreement that we have with them providing us the laptop.

I hear Twitter from my daughter, like, she'll tell me what's on Twitter, I have an account. But I don't have the app on my phone anymore. I really don't look at it. I'll look at Instagram. But it's nothing like I've never found anything. Like for teaching purposes on Instagram. It's usually just and I don't, I don't normally friend My students on Facebook or anything until after they've graduated. The only exception was probably my daughter's year when she was going through high school. I was friends with, you know, her friend's parents. So therefore, and then kids from church. You know, I've had several kids that end up in my classroom that has been in kids church, and I've been friends with them such. I mean, go going back to like Blake Walker and Levi Walker and the coals and Tanner Ashton, you know, so there's been those that I can connect with. 


\section{APPENDIX H}

\section{Participant 5 Interview Transcripts}

So, for me, I think it was connectivity, like, connecting with other people across the United States that you don't necessarily know but you can learn from their experiences. And I mean I don't know these people, but, you know, when I got hired to middle school and my field especially special education has a really high turnover, and Taylor County. So, when I was hired, you know, normally you kind of look towards the people that has been in your content area for a long time to permit to worship and getting ideas and things like that. But with special education. That was difficult because most of the people, especially the year I was hired were like, you're like, you're like this people in the in the staff and things that don't know.

But, so like my hiring year. Most of the special ed teachers at the middle school were brand new, except for maybe one or two. And, or had like maybe one year under their belt and we're straight out of college, whereas I had for multiple years so I did have that experience at least and I had something special. But there were a lot of things I didn't know and understand and you know how to, how to properly differentiate for students. I was looking and searching for best practices and ideas, so I went to YouTube, I mean YouTube is like my go to. And I started following other special ed teachers that were teaching the same grade level as me and I started watching what they were doing learning from their experiences. And then just kind of piecing together from each person and pulling things that I can implement and work for me and sometimes, like, I would try things and they wouldn't work. And, you know, I would throw that idea out, and then maybe something that didn't work for them. I was like oh that's it. Actually, I think I could get that to work in my classroom. So, I went in, in the beginning, I've relied heavily on watching YouTube videos, other teachers and their channels and learning from what they were doing, and trying it on my own. Even things like setting up their classrooms and things like that. Yeah, back to what I was saying, you know, normally you, you look to the people in your, in your own school that had been doing it longer than you, to help you out and not having that, that, that was really difficult it was kind of like blazing your own trail. There were also a lot of changes in special education at the time too. So, it was just really hard. So that definitely helped me. And then another thing with special education, that's different kind of than the general ed class. You have to plan individually for each specific student. And according to what their IEP goals are and or just one kid might be on a third grade reading level in the sixth grade and then you've got another kid that's on a kindergarten level in the sixth grade.

So, time management within a small block for a class period was really difficult for me in the beginning, and I struggled to put together a schedule that fit my specific needs in my classroom. And so that's another thing I went to YouTube for was I started going to some of these teacher planning channels and listening to how they set up their schedules and things like that and then just started. I learned from that, that how to what's called ability grouping, kids. So, to maximize your time so if you've got two or three kids that are on a kindergarten level and two or three kids that are on a fifth-grade level, then you spend so much time with that one group while the other group is doing something independently and then you switch. So, so you, you are feeling like you actually are gauging what the ability of each kid is versus just feeling like you're all over the place and don't know if you're helping anyone. So that's another thing I am getting a planner I'm like planning out my time and for the whole week. So, I learned a lot about that on YouTube. So, my next I put my top three. YouTube is my number one. Number two is Pinterest shocker Pinterest I use a little bit differently, it's more of like my resource page. So, if I'm if I've got a certain content that I need to present for that week. I'll go to Pinterest and I'll look up ideas to make it creative and more engaging. So, for Pinterest it's like I might go check out other teachers anchor charts. Or I might I might go see if they have a cool unit that is already scaled down for Special Ed, I mean I have enough work on my plate. All 
the time. So, if somebody else has done it and tried it and it's already set up there for me to use, then I'm doing it. Yeah, and so Pinterest. Pinterest is a good. That's my resource spot. And not so much for networking there; I mean you do, I have been introduced to some. Some people on Pinterest that that I've went to YouTube but started following when I found out they had a channel--but for that is more for resources for me. And then Petras. Am I skipping questions I think I'm covering a bunch of things all at once. That's okay. Okay, I'm gonna break it all apart anyway. Okay. So, Pinterest also kind of led me to. Teachers Pay teacher's,

Teachers Pay teacher's, which is kind of like resource, networking, all just combined in one spot. And one thing I love about Teachers Pay Teachers, is you're kind of getting all of the things that I've been talking to you about so far in this one package so you have teachers who have been in the field for a long time and have a lot of experiences and are able to take their ideas and form a resource that is readily available and ready to use for teachers. So, there's that. And then you also have the resource part of it, you can find pretty much anything you know like if I'm. I even use it now even though I'm still in high school, you know it's like if you are looking for, you know, I'm teaching algebra right now specialized so it's hard for me to scale that down so sometimes I mean there are certain concepts they really have to have so just it's hard to scale that down. Whereas in middle school it's like okay if they're working on division when you start with addition. And you start with repeated addition, and then you work up to multiplication then you work up to division but with these higher-level math skills it's completely different. So, I've gone to Teachers Pay Teachers and I found actual resources where, you know, there are high school teachers teaching algebra that already have an entire unit that's designed for special ed kids and interactive and so it takes a lot of work, away from my, my job. And then I just implement what I know has already been tried and tested by a seasoned teacher, and that's been very helpful to me. And I used to I mean I used to pay teachers, all the time. Like, weekly, I have resources from them that I use.

Um, so, Facebook, I don't use as much, but I am a part of some groups on Facebook. As far as connecting with professionals and leaders in the field, I am a member of a few teacher groups I'm a member of a few of you in groups. I don't use Facebook that much because sometimes I find, you know whatever hot button topic is happening, it becomes a forum for a lot of drama sometimes and versus like actual sharing some of them I'm muted. But then you do have some like I have some math groups that I'm a part of and people share resources and ideas and I have used some of that but I don't use Facebook as much Instagram I use a little bit but not much. It's more like following people versus I don't really get resources there, it's more like following and current event type things. I do, so I have done for professional development I have done lots of webinars, but I don't know that they're attached to like would zoom be considered, social media, I don't know. I do webinars and things online you do.

I do webinars, because that's just something you can you know you can do and do it from the comfort of your own home, especially right now. Participate in educational groups or forums, I mean that would kind of be like Facebook, but I don't really post that much I just kind of go in and see what other people are doing and sharing and occasionally I'll ask the question, but

I guess that would go with soliciting advice as well. It just takes so much of your workload off of you, to be able to use other people's resources. 